\title{
18 MOLLUSCA: CAUDOFOVEATA, MONOPLACOPHORA, POLYPLACOPHORA, SCAPHOPODA, AND SOLENOGASTRES
}

\author{
Julia D. Sigwart and Lauren H. Sumner-Rooney
}

\section{INTRODUCTION}

Molluscs are the second-most speciose metazoan phylum, after Arthropoda, and arguably molluscs demonstrate the largest morphological disparity. The dramatic body-plan modifications and changes among the molluscan clades leave few consistent characters that can be directly compared across all eight living classes ${ }^{1}$. The living diversity encompasses bivalves (clams, mussels, and shipworms), gastropods (snails and slugs), and cephalopods (squid and octopuses), each of which are treated in separate chapters in this volume, and five 'minor' or more precisely less speciose classes that we discuss in this chapter (Fig. 18.1).

The five groups covered here-Caudofoveata (chaetoderms), Monoplacophora (headless deep-sea limpets), Polyplacophora (chitons), Scaphopoda (tusk shells), and Solenogastres (neomeniomorphs) — are addressed in alphabetical order in a deliberate effort to treat each group on its own evidence and to avoid suggestion of any specific phylogenetic hypotheses. These animals are all exclusively marine, and live as benthic or infaunal species. They are less commercially exploited than the three major classes, but nonetheless demonstrate extensive diversification within each clade, and many are locally abundant and exert significant ecosystem control (Dethier and Duggins 1984, Shimek 1988). Careful consideration of these groups is essential towards resolving larger questions of molluscan, and metazoan, evolutionary dynamics.

Molluscs are soft-bodied animals that ancestrally possess a muscular locomotory foot, a mineralized proteinaceous tooth structure called the radula, and a calcium carbonate shell which is anchored to the foot by dorsal-ventral muscle bundles. The mantle is a tissue layer that creates a chamber that houses the viscera and secretes the shell, though this is subject to interpretation and modification especially in these 'minor' classes. Chemosensory epithelia called osphradia, apparently unique to molluscs, are present in most members of some classes (Lindberg and Sigwart 2015). All

${ }^{1}$ Each of these clades, with equivalent Linnean rank as a class, represents a monophyletic group hierarchically subordinate to the total-group Mollusca. of these structures are lost in one or more of the eight living classes: the vermiform Caudofoveata have no foot, Bivalvia have no radula, at least Scaphopoda, Monoplacophora, Solenogastres, and Caudofoveata lack an osphradium, Caudofoveata and Solenogastres also lack shells. Extensive shell loss and modifications are seen repeatedly in Gastropoda, Bivalvia, Cephalopoda, and to a lesser extent Polyplacophora.

The dynamics of these extreme body plan modifications within a single phylum present a fundamentally important question in evolutionary biology. There is no clear consensus on the topology of phylogenetic relationships within the molluscan classes (Sigwart and Lindberg 2015). The challenging problem of resolving the sister relationships of such variable forms has perhaps been further hampered by a historical focus on shell forms, which are evidently extremely plastic. Two alternative hypotheses are both supported by molecular and morphological evidence, and the differences between these two topologies provide little clarity on the sister relationships between most clades. The 'Aculifera' hypothesis unites the vermiform aplacophorans (Caudofoveata and Solenogastres) and the eight-valved Polyplacophora, in a clade opposed to 'Conchifera', containing the other five classes. This topology is supported by the only phylogenomic analysis of total-group Mollusca to date (Smith et al. 2011), and fossils of 'armoured aplacophorans', sharing characters of both chitons and spiculose vermiform molluscs, have been described as transitional aculiferans (Sigwart \& Sutton 2007, Sutton et al. 2012, Sutton and Sigwart 2012). The almost completely contradictory 'Serialia' hypothesis was originally proposed from the first molecular genetic sequence recovered from a rare living monoplacophoran, and has been subsequently recovered by independent analyses with multiple monoplacophoran species (Giribet et al. 2006, Kano et al. 2012, Stöger et al. 2013). The topology associated with Serialia is supported by strong anatomical arguments and fossil stratigraphic analysis (Stöger et al. 2013). Very few studies have included all eight classes (Giribet et al. 2006, Smith et al. 2011, Stöger et al. 2013), and more sources of independent evidence, representing all groups, are required to resolve molluscan relationships. 


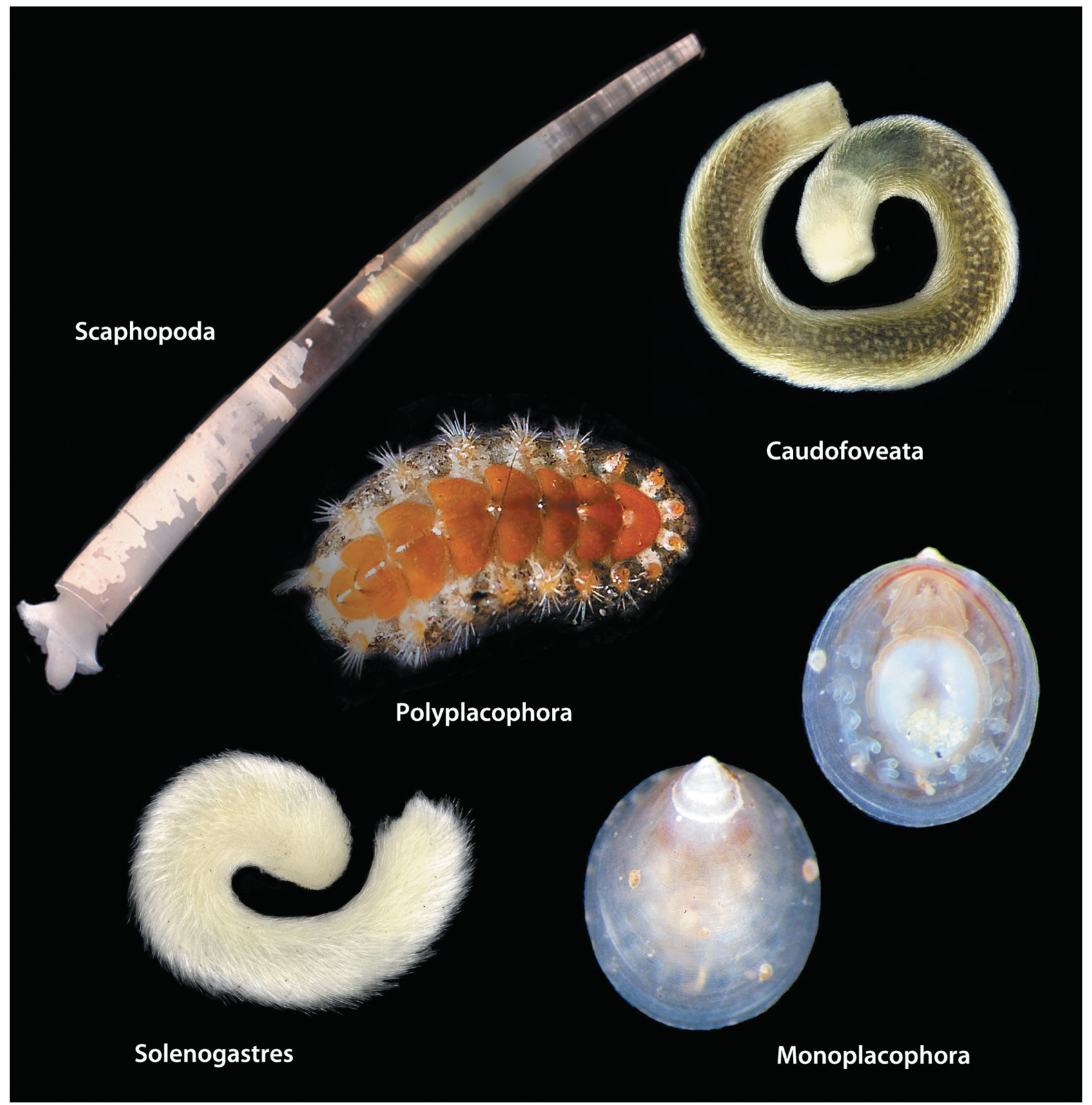

Fig. 18.1. The minor molluscan classes. Caudofoveata, Scutopus robustus (photo by Elena Gerasimova); Monoplacophora: Laevipilina theresae (photo used with permission of Michael Schrödl); Polyplacophora: Acanthochitona

Nervous systems offer a source of morphological character data that can be directly compared across all classes and, crucially, with putative proximate outgroup phyla. This neurophylogenetic approach has been used productively in studies of other metazoan groups (Harzsch 2006, Strausfeld and Andrew 2011). This chapter reviews the nervous system architecture, sensory systems, and developmental process in each of the five minor molluscan classes. We briefly review the diversity of taxa within each class that have contributed to the available literature, and the history of their study. Bearing in mind the need for a clear, comparative basis of neural characters, we have frequently fascicularis; Scaphopoda, Rhabdus rectius; Solenogastres, Amboherpia hetereotecta (photo by Elena Gerasimova).

reinterpreted the specific vocabulary in the published accounts of each class in order to implement consistent descriptions. The terminology follows the definitions suggested by Richter et al. (2010), based on our interpretation of anatomical evidence, even where different terms may have been traditionally used by some (or all) other authors. The nervous systems of these animals are mostly simple, and potentially secondarily simplified in some cases. Our choice of language is, as much as possible, neutral on all questions of polarity, and strictly descriptive.

The molluscan nervous system is composed of an oesophageal nerve ring, which connects, where they are distinguished, 
two pairs of cerebral and pedal ganglia. The cerebral ganglia (or the corresponding region of the nerve ring) emit the lateral nerves; in some cases there is a proximal pleural ganglion on the lateral nerve. Depending on the body form of the specific mollusc, these may also be called the visceral nerves or pallial nerves. The cerebral ganglia also emit the buccal nerves, which innervate the feeding structures and usually bear buccal ganglia. The pedal ganglia emit the pedal nerves, which, like the lateral nerves, are often medullary in nature. Positional homologies to this fundamental architecture underpin all descriptions herein (Fig. 18.2).

All of these molluscs lack conventional cephalized senses. They all have no eyes, with the exception of lensed and pigmented eyes embedded within the shell valves of some chitons. They do possess remarkable sensory adaptations specific to their environments. The sensory network of shell nerves in polyplacophorans in some cases is adapted to represent an image-forming compound eye over the total animal dorsal surface (Speiser et al. 2011).
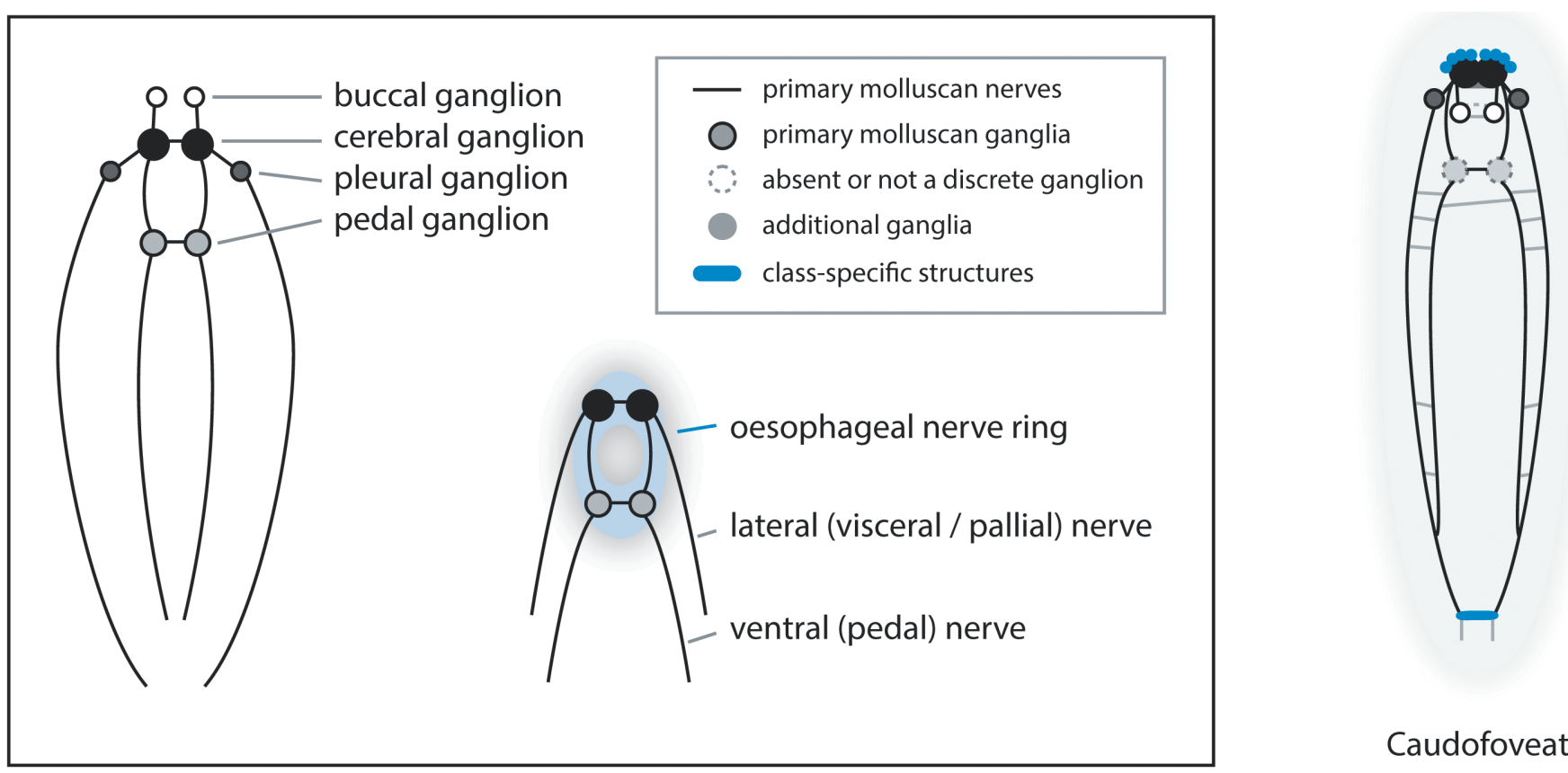

\section{Caudofoveata}

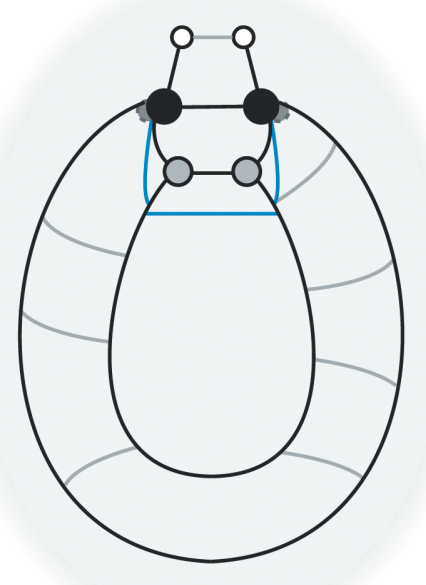

Monoplacophora

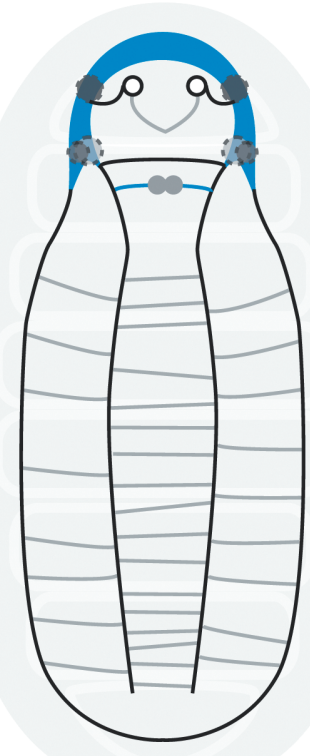

Polyplacophora

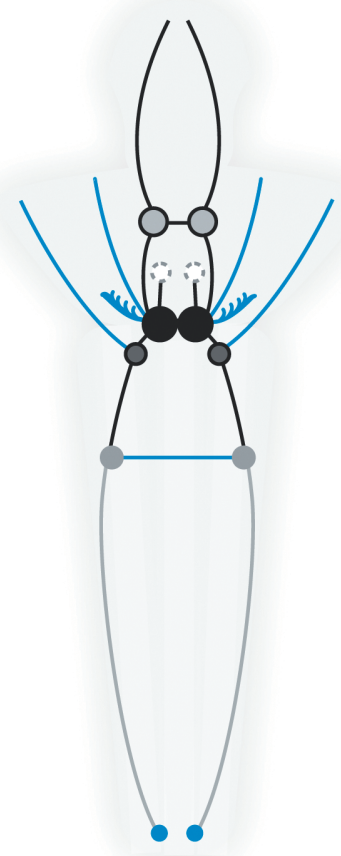

Scaphopoda

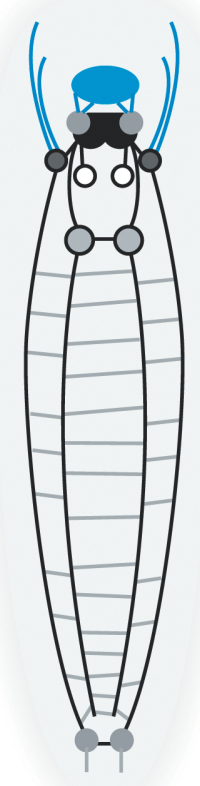

Solenogastres

Fig. 18.2. Schematic diagrams showing the nervous systems of the five minor molluscan classes (as labelled), and a generalized molluscan nervous system (top left, inset). 
Scaphopods have hundreds of super-elastic filamentous ganglionic tentacles (captacula) which can stretch multiple times the length of the body to seek food in the surrounding sediment. Most of these molluscs also possess complex subradular organs that apparently taste potential food, and various putatively chemosensory organs of undetermined function.

The minor molluscan classes represent the key groups for understanding fundamental processes in the evolution of animal body plans. While the essential knowledge on the nervous systems in each of these classes is well established, these animals still possess a rich and largely untapped supply of novel characteristics, sensory adaptations, and new discoveries in the evolution of nervous systems.

\section{CAUDOFOVEATA}

Caudofoveates (sometimes referred to as Chaetodermomorpha) are vermiform marine burrowing molluscs that generally inhabit soft sediments at depths to $6000 \mathrm{~m}$; but they are found up to 8 $\mathrm{m}$ and in one exceptional instance $3 \mathrm{~m}$ deep (Redl and SalviniPlawen 2009, Scheltema 1995). The animals are relatively small, ranging in adult size from $2-40 \mathrm{~mm}$, and the elongate body is divided into distinctive anterium, trunk, and posterium regions. Caudofoveates lack a head, foot, and shell and possess a pair of gills in a small posterior mantle cavity. These animals are covered by a cuticle and a coat of calcareous sclerites, and a thick cuticular oral shield. This muscular structure is variable in morphology among taxa and is a sensitive burrowing organ; its presence is part of the distinctive anatomy that separates the two aplacophoran groups (Salvini-Plawen 1972, 2003). The muscular anterior part of the body is used to burrow into sediment, where caudofoveates feed on detritus, diatoms, and foraminiferans, with the posterior mantle cavity and gills protruding from the surface (Mizzarro-Wimmer and Salvini-Plawen 2001, Salvini-Plawen 1975). The sexes are separate, adults broadcast spawn and the zygotes develop into trochophore larvae, though knowledge of larval development remains patchy (BucklandNicks et al. 2002, Nielsen et al. 2007). To date, around 150 species have been described in three families: Chaetodermatidae, Prochaetodermatidae, and Limifossoridae (Redl and SalviniPlawen 2009, Todt et al. 2008). Historically, caudofoveates were included with Solengastres as a class, Aplacophora, but given the numerous anatomical as well as molecular genetic differences, they are treated as two separate clades. The difference in locomotion between caudofoveates and solenogastres (burrowing or gliding) is reflected in the different arrangements of their nervous system (Scheltema et al. 1994).

\section{Nervous system architecture}

Caudofoveates have a typical molluscan tetraneural nervous system within their unusual elongate body plan. The cerebral ganglia are connected to the proximal end of the pedal nerve cords by the cerebropedal connectives and the anteriormost pedal commissure to form the oesophageal nerve ring. There are two pairs of medullary cords which run longitudinally through the body. The ventral nerve cords, emitted by the pedal ganglia, have few branching nerves to the ventral part of the body, as the foot is entirely lacking. The lateral nerve cords originate in the cerebral ganglion and supply the mantle and the internal organs, emitting more nerves in the anterior region, which is used for burrowing (Salvini-Plawen 1985, Scheltema et al. 1994).

The paired cerebral hemiganglia are fused in Chaetodermatidae to give one large cerebral ganglion, but in Prochaetodermatidae they are not fused; these have been described in detail in more than five species (Redl and Salvini-Plawen 2009, Salvini-Plawen 1985). This combined brain is composed of an axonal core surrounded by a layer of cell bodies. The neuropil is partitioned into distinct anterior (around one third of total volume) and posterior groups of axons by glial membranes and neural somata (Fig. 18.3; Faller et al. 2012, Shigeno et al. 2007). The overall shape of the ganglion is lobed, with distinguishable anterior, posterior, and dorsal aspects, though much of the dorsal expansion appears to be cell bodies only with no neuropil (Faller et al. 2012, Shigeno et al. 2007). Anterior to the cerebral ganglion there are three or more pairs of frontal swellings that innervate the mouth and the oral shield (Heath 1911). These have been previously referred to as 'precerebral ganglia', however they do not contain a central neuropil and are made almost entirely of neural somata (Faller et al. 2012, Shigeno et al. 2007) and so do not qualify as true ganglia. There are tubulin-reactive tracts within the cerebral ganglia which directly innervate the frontal swellings and possibly the sensory ciliary cells in the oral shield (Shigeno et al. 2007).

The cerebral ganglia emit the cerebrobuccal, cerebropedal, and cerebrolateral connectives from their lateral edge. These three originate in a single nerve bundle and branch shortly after leaving the cerebral ganglion, with the cerebrobuccal connective

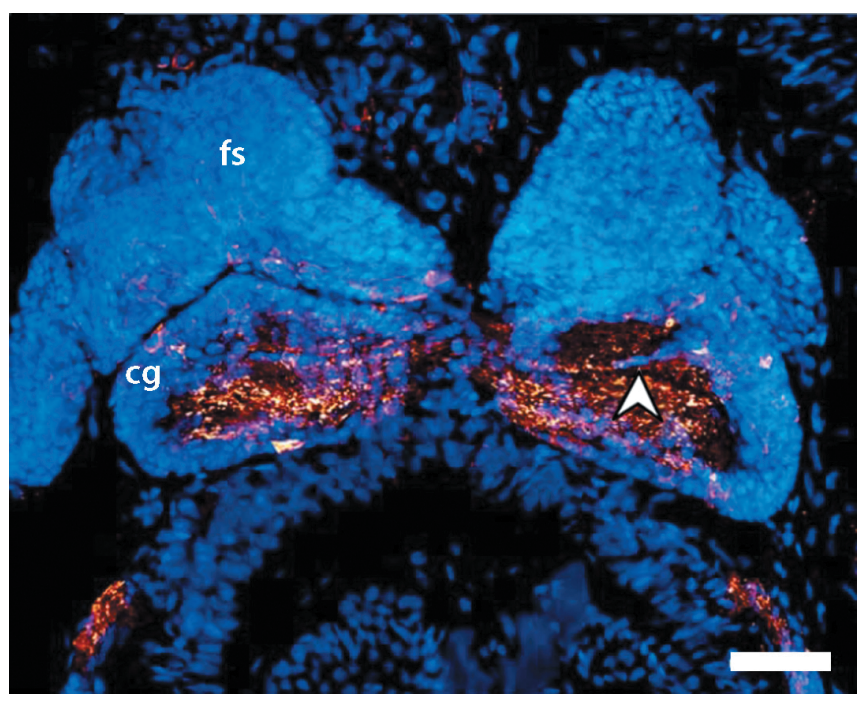

Fig. 18.3. Caudofoveata: The cerebral ganglion and anterior nervous system of Scutopus ventrolineatus, reproduced from Faller et al. (2012), with kind permission from Springer Science and Business Media. Frontal section showing FMRFamide-like immunoreactivity (orange) and DAPI nuclear labelling (blue). Note the subdivision of the cerebral hemiganglia by a layer of cell bodies (arrowhead). cg: cerebral ganglion; fs: frontal swelling, scale bar $40 \mu \mathrm{m}$. 
branching first, followed by the cerebropedal connective (Heath 1911, Salvini-Plawen 1975). The paired buccal ganglia innervate the mouth and feeding apparatus, these are lateral and posterior to the buccal mass and are joined by one or more commissures (Heath 1911, Hyman 1967, Redl and Salvini-Plawen 2009). The lateral and ventral nerve cords are medullary, comprising a neuropil core surrounded by neural somata (Salvini-Plawen 1985). Shortly after their divergence from their origin in the cerebral ganglia, the nerve cords form serial swellings; these have previously been described as 'ganglionic' but they are not isolated by non-medullary nerve connectives, and distinct pleural or pedal ganglia are not evident. The width of the central neuropil varies throughout the nerve cords, forming several more discrete bumps, particularly in the anteriormost parts (Faller et al. 2012, Shigeno et al. 2007). Connectives between the lateral and ventral nerve cords are most numerous in the anterior region of the body (Heath 1911; Salvini-Plawen 1985). There are a few pedal connectives in the anteriormost part of the trunk, but they are not present in the rest of the body (Heath 1911, Redl and Salvini-Plawen 2009, Salvini-Plawen 1985).

At the posterior end of the animal, the lateral and ventral nerve cords fuse to form a single nerve cord which extends further posterior before joining at the suprarectal commissure (Salvini-Plawen 1975, 1985). The suprarectal commissure contains a distinct oval neuropil at its centre and innervates the small posterior mantle cavity as well as the pair of gills (ctenidia) found therein (Salvini-Plawen 1985, Scheltema et al. 1994).

\section{Sensory systems}

Caudofoveates lack both eyes and statocysts (Shigeno et al. 2007). The epithelium behind and lateral to the mouth is covered by a thick specialized, cuticularized muscular layer known as the oral shield or pedal shield. Although present in all caudofoveates, the size and development of the oral shield vary in different taxa, even appearing to be bi-partite in Prochaetoderma and Limifossor (Salvini-Plawen 1985). The following description of ultrastructure relates to Scutopus, Falcidens, and Chaetoderma. Unlike the surrounding body, the oral shield contains large granules and interdigitating microvilli from the epithelium below (Scheltema et al. 1994). Glandular mucous cells open around the periphery of the shield, and there are sensory cells in the underlying epithelium, with cilia that penetrate the cuticle and are exposed to the surrounding environment (Scheltema et al. 1994). The ciliary cells within the oral shield are connected to primary or secondary neurons in the frontal (precerebral) swellings, which in turn connect them to the cerebral ganglion (Hyman 1967, Shigeno et al. 2007).

The dorsoterminal sense organ is a longitudinal groove located dorsally and slightly anterior to the mantle cavity opening at the posterior end of the body. It is innervated by the suprarectal commissure, and surrounded by specialized scales. The epithelium either side of the groove is raised, consisting mainly of supporting cells and a few mucous cells and covered with a thin cuticle and a mucous layer. Within the groove, there is no cuticle. The epithelium supports a microvillous border, and is mainly composed of supporting cells, though there are two sensory cell types as well: basal cells bearing epithelial projections, and ciliary cells (Haszprunar 1987a). Although the dorsoterminal sense organ is well developed in Chaetodermatidae, it is reduced in Limifossoridae and vestigial in Prochaetodermatidae, with little swelling and no discernible innervation (Haszprunar 1987a). Multiciliary sensory cells are exposed to the environment, and collar receptor cells may also be present (Scheltema et al. 1994). The organ has been proposed to play a chemoreceptive role in reproductive behaviour (Salvini-Plawen 1985, Haszprunar 1987a), but this has not yet been tested experimentally.

\section{Larval development}

The trochophore larvae of caudofoveates undergo a gradual metamorphosis on settlement, but information about the development of the nervous system has not yet been documented. An apical ganglion is visible in developing larvae via TEM visualization ten days after hatching, and the anlage of a cerebral ganglion becomes visible at 12 days post hatching, but no other developing nervous structures have been observed (Nielsen et al. 2007).

\section{Observations}

Caudofoveata was only recognized as a separate class relatively recently, in the middle of the twentieth century. It was Boettger (1956) who described the class, and not until the seminal work of Salvini-Plawen $(1968,1978)$ was any specific attention paid to these animals. The other vermiform class, Solenogastres, is more speciose and more accessible, thus most generalized results about 'aplacophorans' have reflected knowledge of solenogasters rather than caudofoveates. Indeed, the unified taxon Aplacophora is still incorporated into more recent studies, despite the anatomical differences between them (e.g. Kocot et al. 2011). These differences have been used in some arguments about the polarity of character states in comparing vermiform to other molluscs (Salvini-Plawen 1980). Neural characters have been described from at least ten species, covering all three living families, though these are predominantly from Chaetodermatidae, and with very few studies of members of Prochaetodermatidae (although that family contains around $30 \%$ of living species). The available comparative studies indicate substantial neuroanatomical diversity.

In most species there is clearly a well-developed brain, and the subdivision of the cerebral neuropil into distinct regions is more complex than in any other class in this chapter. Whether the frontal swelling anterior to the cerebral ganglion is homologous to positionally similar structures in Solenogastres would need rigorous immunocytohistochemical study (Shigeno et al. 2007). The animals seem to rely on chemosensory modes, which may be adaptations to their burrowing lifestyle.

\section{MONOPLACOPHORA}

The first identification of a living monoplacophoran is considered one of the great discoveries of twentieth-century science, following a similar story arc to the Wollemi Pine 
(Wollemia nobilis) and Coelacanth (Latimeria chalumnae), as all were described from fossil evidence from the Cambrian to Devonian, and then unexpectedly found alive. In the case of monoplacophorans, several species were collected earlier than the famous discovery of the Galathea Expedition in 1957 (Lemche and Wingstrand 1959), but those earlier specimens were misidentified as patellogastropod limpets (Lindberg 2009). The term Monoplacophora includes a number of fossil species that may not be allied to Tryblidia, which includes the living species. Monoplacophorans have a subconical dorsal shell with a curved anterior apex, and a ventral foot and mouth. Although superficially similar to patellacean gastropods, the monoplacophoran animal lacks a head or eyes; it attaches to the shell with a distinctive series of paired dorsoventral muscles, and has gills that grow iteratively in the ventral pallial cavity on either side of the foot (Fig. 18.1). The headless, limpet-like monoplacophorans encompass 25 living species; all inhabit the deep sea (175-6400 m), and most, with very few exceptions, are known from a small number of specimens (Wilson et al. 2010). Although of great interest to evolutionary biology, anatomical descriptions, including neuroanatomical features, have been made from only seven species. This provides limited scope for comparative studies and generalizations and comparisons with other classes should be considered with some caution.

\section{Nervous system architecture}

The circumoesophageal ring comprises two pairs of ganglia (Fig. 18.4): the cerebral (anterior) and the 'labial' ganglia, which are positionally homologous to the pedal ganglia (Fig. 18.2). These are connected by the cerebral and pedal (or post-oral) commissures and emit the lateral (cerebral ganglia) and ventral (pedal ganglia) nerve cords. The cerebral ganglia are covered by many cell bodies, and form the lateral parts of the circumoesophageal ring (Lemche and Wingstrand 1959). Within each
A
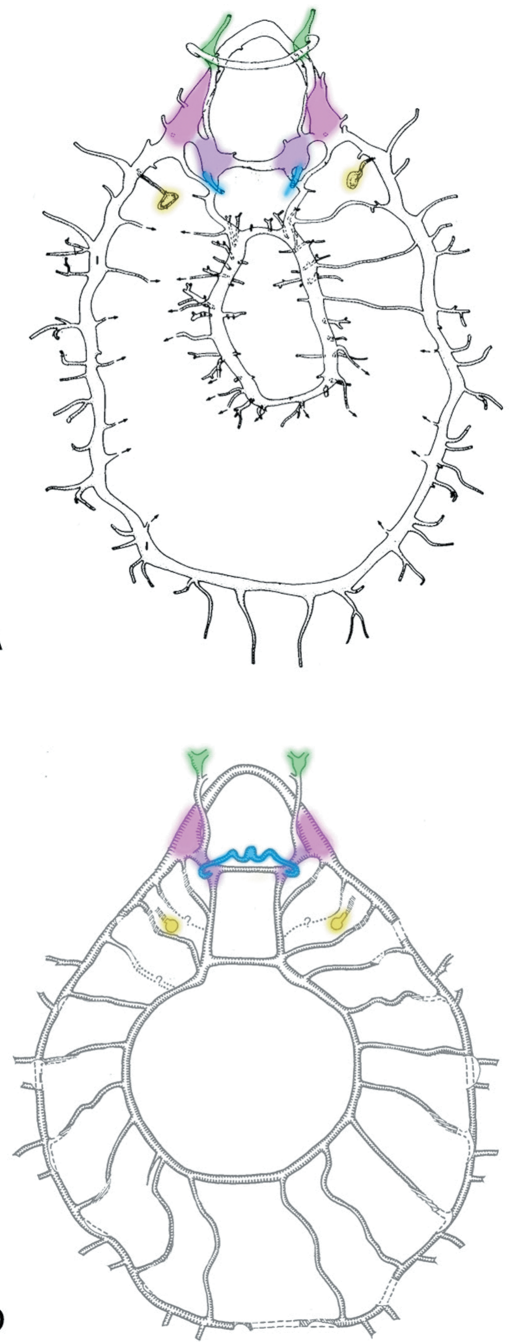

B
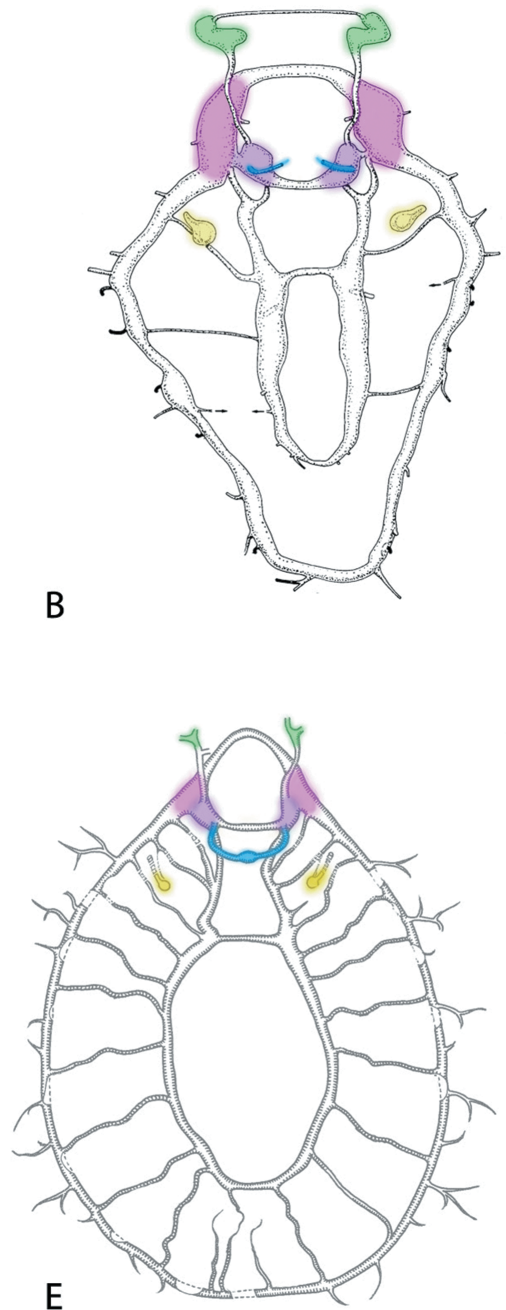

C

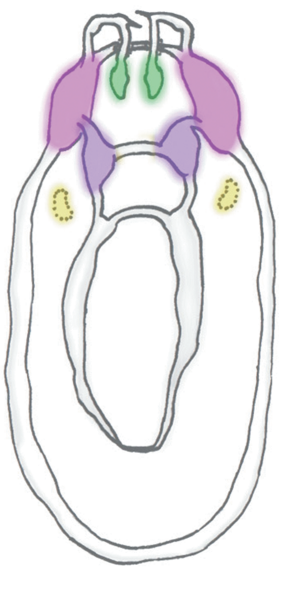

\section{buccal ganglia}

cerebral ganglia pedal (labial) ganglia subradular nerves / ganglion statoliths
Fig. 18.4. Monoplacophora: General nervous system of five monoplacophoran species, highlighting the variable size and morphology of elements of the anterior nervous system. A: Laevipilina antarctica redrawn from Schaefer and Haszprunar
(1997), B: Micropilina arntzi redrawn from Haszprunar and Schaefer (1997a), C: Micropilina minuta, redrawn from Haszprunar and Ruthensteiner (2013), D: Neopilina galathaea, E. Vema ewingi, both redrawn from Wingstrand (1985). 
ganglion the neuropil core is divided into two confluent parts (Wingstrand 1985), and each has swellings at their junctions with other nerve cords: anteriorly with the cerebral commissure, and posteriorly where the lateral nerve cords originate.

The cerebral ganglia are connected proximally to the pedal ganglia, which are themselves joined by the pedal commissure. The pedal ganglia were identified as an enlarged area of the cerebral ganglia by Wingstrand (1985) and clarified as separate structures by Schaefer and Haszprunar (1997) and Ruthensteiner et al. (2010), but they vary taxonomically. In the two smaller Micropilina species, both pairs of ganglia are particularly large and distinct, yet in Vema and Neopilina the pedal ganglia are small enough that the authors did not distinguish them as separate structures (Fig. 18.4D, E). The buccal nerves originate at a point intermediate between the cerebral and pedal ganglia (possibly with the exception of $M$. arntzi, where they appear to originate in the cerebral ganglia; however, given the incredibly diminutive size of $M$. arntzi, small nerves and connectives could not be visualized, so it is possible that finer nerves run to the true connection further posterior in that animal). They project dorsal to the circumoesophageal ring and extend anteriorly, passing around the pharynx, to which they emit one nerve before forming distinct buccal ganglia dorsal and anterior to the cerebral commissure (Lemche and Wingstrand 1959). A thin commissure between these has been found in some species and is inferred to exist in others.

A subradular nerve originates from a central dorsal point in each pedal ganglion and connects proximally to the dorsal side of the prominent (single, unpaired) subradular organ, in the transverse fold of the subradular sac. The subradular nerves do not apparently fuse to form a commissure or ganglion, as suggested in early descriptions (Lemche and Wingstrand 1959); Schaefer and Haszprunar (1997) suggested this structure was better described as 'neurolymphoid' intraepithelial tissue.

The pairs of major longitudinal nerve cords originate from the cerebral ganglia (lateral cords) and pedal ganglia (ventral cords). Histologically they are medullary, with a layer of cell bodies surrounding a central neuropil bundle, but not ganglionic, and the anteriormost parts lack cell bodies entirely (Lemche and Wingstrand 1959). The ventral cords are substantially thicker in Micropilina spp., but the ventral and lateral cords are around the same diameter in other taxa examined (Fig. 18.4). From their point of origin in the posterior pedal ganglia, the ventral nerve cords initially extend caudo-medially and run close together. Where they enter the anterior foot musculature, they are connected by the pedal commissure (Lemche and Wingstrand 1959). This has been described as bearing a 'ganglionated swelling' (Wingstrand 1985), but not a ganglion. Posterior to this, the ventral nerve cords separate, extending laterally and running along the periphery of the foot. They innervate the foot with short and irregularly spaced medial foot nerves, and more numerous and more regular lateroventral foot nerves (Lemche and Wingstrand 1959). There are no other connectives crossing the ventral nerve ring until the pedal cords join again in the posterior pedal commissure, a connective ventral to the posterior intestine and short of the posterior edge of the foot. The diameter and length of the pedal nerve ring is strikingly different among species, and apparently reflects morphological differences in the foot.
The lateral nerve cords extend for the full length of the body from their origins in the cerebral ganglia, ending in a suprarectal commissure ventral to the rectum. Small distal pallial nerves are emitted irregularly throughout the pallial cavity, branching further towards the ventral body surface and eventually associating with the basal lamina. The lateral nerve cords also innervate the gills, emitting a nerve slightly anterior to each gill. These nerves sometimes appear to share an origin with pallial nerves, but not consistently (Lemche and Wingstrand 1959). The lateral and ventral nerve cords on each side of the body are connected by many lateroventral connectives, smaller nerves which pass between the dorsoventral shell muscles throughout the length of the body (Wingstrand 1985). The anteriormost of these connectives links the posterior extent of the cerebral ganglion and the pedal ganglion, but separate and posterior to the circumoesophageal nerve ring. This can form a Y-junction at the top of the ventral nerve cords, with the two anterior branches being the cerebropedal connective and the thin connective between the pedal ganglion and the main ventral nerve cord (Fig. 18.4B: Micropilina arntzi). The second lateroventral connective innervates the statocysts and tentacles. All others attach to the anterior face of the retractor muscles (Lemche and Wingstrand 1959, Wingstrand 1985) or may be less regular in some species (Schaefer and Haszprunar 1997).

\section{Sensory systems}

Monoplacophorans lack a head; they have no eyes or eyespots. An osphradium has not been identified in any species (Lemche and Wingstrand 1959, Ruthensteiner et al. 2010).

The subradular organ is large and prominent in all species examined (Haszprunar and Schaefer 1997b). This 'tasting' sensory organ is an extension of the subradular sac, ventral to the radula, with a higher epithelium than the remainder of the sac lumen (Lemche and Wingstrand 1959). In Laevipilina antarctica, this sensory epithelium, which is innervated by the subradular nerves, largely consists of tall, columnar multiciliary and microvillous cells with basal oval nuclei. The cells are often separated by intercellular pits; the cilia are long, but with weak rootlets and few associated mitochondria (Haszprunar \& Schaefer 1997b).

A pair of statocysts are found positioned laterally in the body, in between the postoral commissure and the pedal commissure (that is, slightly anterior to the foot). The statocysts appear to be innervated by the second connective joining the lateral and ventral major nerve cords, but some evidence suggests the statocyst nerves arise directly from the lateral nerve cord. In Micropilina arntzi, one juvenile specimen showed a statocyst nerve emerging directly from the lateral nerve cord, and in Laevipilina antarctica, Schaefer and Haszprunar (1997) observed a potential statocyst connective. In both cases these were in the same position as in Vema and Neopilina, i.e. posterior of the cerebropedal connective and thus clearly posterior of the cerebral ganglion. This connection is unusual, as in all other molluscs known to have statocysts they are innervated by the cerebral ganglia. The statocysts are oval-shaped epithelial sacs, containing several statoconia. The epithelium is not uniform in height (Lemche and Wingstrand 1959, Ruthensteiner et al. 2010). The epithelium consists of columnar cells with basal nuclei, and although, putatively, sensory 
hairs have been observed in the ventral side, no sensory cells have been identified (Lemche and Wingstrand 1959). They are filled with an unknown substance which lacks a clear structure (Lemche and Wingstrand 1959, Ruthensteiner et al. 2010). A narrow duct connects the statocyst ventrally to the surface of the roof of the pallial cavity, behind the post-oral tentacles, ending slightly anterior to the position of the statocyst itself (Lemche and Wingstrand 1959, Schaefer and Haszprunar 1997).

The post-oral tentacles are innervated by four nerves: one from the second lateropedal connective as described above, two from the pedal cord itself, and one from the postero-medial part of the cerebral ganglion. They are thought by some to be sensory, however ultrastructural investigation has not revealed any likely sensory structures (Haszprunar and Schaefer 1997b). A pair of pre-oral tentacles are densely innervated and have a thickened epithelium at the tip, suggesting a sensory (possibly chemosensory) role for these appendages (Lemche and Wingstrand 1959).

\section{Larval development}

Because of the inaccessibility of specimens, there is no data available on the larval development of monoplacophorans of any species (Haszprunar and Ruthensteiner 2013). The larval life history of monoplacophorans can be inferred from other deepsea molluscs, which would suggest a free-floating lecithotrophic larva (Gonor 1979). Cleavage was observed in one specimen of Laevipilina hyalina, from a female that emitted oocytes on collection at sea, but development did not continue after first cleavage (Wilson et al. 2010). Specimens of Micropilina arntzi preserved with brooded larvae in situ in adult females provided important ontogenetic evidence about organ systems, but not neurogenesis (Haszprunar and Schaefer 1997a). Micropilina spp. also demonstrates a high degree of progenesis and brooding cannot be assumed to be the typical monoplacophoran habit.

\section{Observations}

Few species have been studied for neuroanatomical purposes and contributed to the descriptions above. The earliest observations made on monoplacophoran neuroanatomy were reported in the Galathea report from specimens of Neopilina galatheae (Lemche and Wingstrand 1959). In total, seven species from four recent genera (out of eight) have been examined. Given the rarity of specimens, this covers an impressive taxonomic range, and among these seven species there is a surprising level of apparent variation in neuroanatomy. These differences merit further investigation of the taxonomic variation clearly present in Monoplacophora. The almost total absence of developmental studies leaves a large hole in our knowledge of monoplacophorans, and any additional research in this field would be welcomed.

\section{POLYPLACOPHORA}

Chitons are benthic marine molluscs that have a distinctive articulating dorsal armature, and a ventral foot and mouth, which they use to graze on rocky substrata. The eight aragonitic dorsal valves are penetrated by a network of sensory shell pores called 'aesthetes'; the valves are surrounded by a muscular girdle, which is covered by a cuticle bearing spines, scales, or other elements, some of which have putative sensory functions. There are around 1000 living species described and the class sensu lato has a fossil record extending to the Cambrian. The sexes are separate and fertilization external, leading to a free-floating trochophore larva, which undergoes a gradual metamorphosis upon settlement to benthic life. Living species of chitons are divided into two subclasses: Chitonida, containing more than $80 \%$ of living taxa is predominantly a shallow water group, and Lepidopleurida, which contains primarily deep-sea species and is the more plesiomorphic group. The two clades are separated by features of the shells and gills, and the presence in Lepidopleurida only of a distinctive pigmented sensory organ called the Schwabe organ (Fig. 18.5).
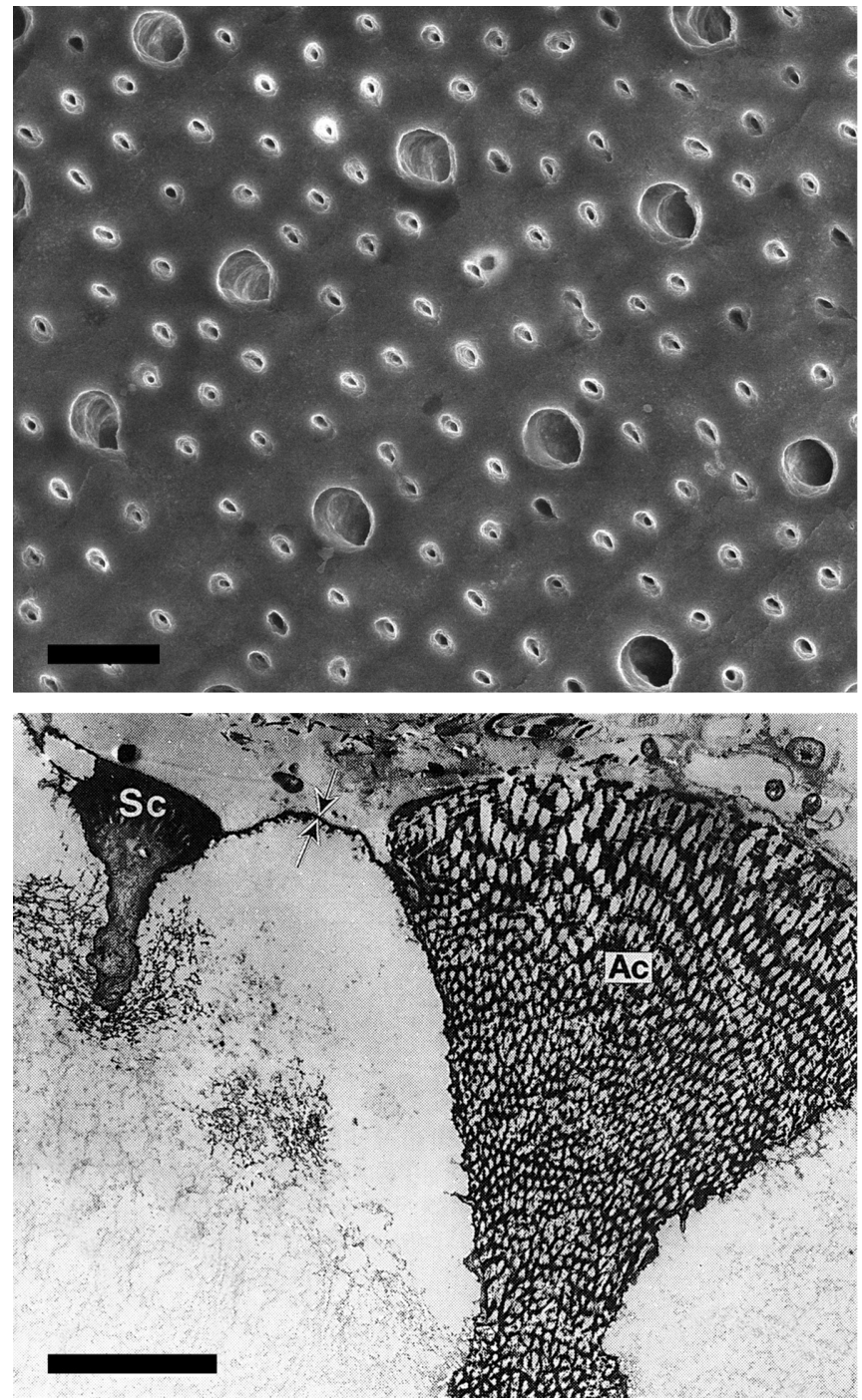

Fig. 18.5. Polyplacophora: Aesthetes, the shell pores in chiton valves. Top, SEM image of the dorsal side of an intermediate valve of Tonicella lineata, after cleaning with dilute hypochlorite to remove tissue from the aesthete canals, scale bar $20 \mu \mathrm{m}$. Bottom, TEM image of a cross-section of a megalaesthete (the larger pores) of Tonicella marmorea, reproduced from Baxter et al. (1987) with permission from John Wiley and Sons. Scale bar $2 \mu \mathrm{m}$. 


\section{Nervous system architecture}

The polyplacophoran nervous system follows a tetraneuralian plan. It is formed of a circum-oesophageal (cerebrobuccal) nerve ring that emits two pairs of nerve cords: the lateral nerve cords, which innervate the pallial cavity, and the ventral nerve cords, which innervate the foot. Histological examinations of the nerve ring and the nerve cords show that they are medullary, organized into a central neuropil and a surrounding layer of somata (Faller et al. 2012, Mizzarro-Wimmer and Salvini-Plawen 2001, Sigwart et al. 2014). The enlarged anterior commissure of the oesophageal nerve ring is not considered to contain cerebral ganglia, though it is substantially thickened anteriorly in at least some species, and at the posterior-lateral margins before dividing into the two pairs of nerve cords (Faller et al. 2012, Sigwart et al. 2014, Fig. 18.5).

Weak buccal nerves originating in the lateral part of the anterior commissure lead to paired buccal ganglia, which are situated dorsal to the anteriormost point of the cerebrobuccal nerve ring. The buccal ganglia are joined by a long commissure that runs posteriorly around the oesophagus and meets dorsal of the subradular ganglia; this juncture between the oesophagus and radular sac has been described as the supraradular ganglion (Gantner 1987) and is present as a paired swelling in some species (Eernisse and Reynolds 1994, Sigwart et al. 2014), but there is no evidence that it conforms to the definition of ganglia used herein. At the posterior connection of the circumoesophageal nerve ring, the anterior origin of the ventral nerve cords is the source of the subradular nerves, connecting to the paired subradular ganglia, which are connected to each other by a small commissure and innervate the subradular organ. These are situated dorsal to the plane of the circumoesophagial nerve ring.

The lateral nerve cords originate from the lateral-most point of the cerebrobuccal nerve ring. They initially extend laterally, and then run along the roof of the pallial cavity, close to the ventral body wall, until the two nerve cords form a suprarectal connective dorsal to the anus. (This is not a commissure sensu stricto; Faller et al. 2012.) The lateral nerve cords emit smaller nerves to the pallial cavity, and an efferent and an afferent nerve to each gill.

The origins of the ventral nerve cords are slightly further posterior than those of the lateral nerve cords, in the posteromedial region of the cerebrobuccal nerve ring. The ventral nerves turn slightly medially, towards each other, before entering the foot. Within the foot they run parallel to each other until slightly before its posterior edge, where they are joined by the subrectal commissure. The two lateral and ventral nerve cords on each side are connected by smaller commissures. The ventral nerve cords are also connected to each other by crossing commissures, the largest is posterior of the subradular nerves, but connections occur down the whole length of the body to give an irregular ladder-like appearance to the overall nervous system (Fig. 18.2).

A glio-interstitial system has been identified in several species in Chitonida (Eernisse \& Reynolds 1994).

\section{Sensory organs}

Chitons lack statocysts, cephalic eyes, tentacles, and in some cases osphradia. Pallial sense organs differ substantially between the two orders, Chitonida and Lepidopleurida. The well-developed subradular organ lies within the radular sac, and is protruded to apparently taste the substratum before grazing. The epithelium is ciliated and contains interspersed microvillous cells with secretory granules (Boyle 1975).

All living chitons have numerous sensory pores and sometimes eyes in their valves, collectively called aesthetes (Moseley 1885). The pores are analogous to the punctae of brachiopods. The aesthetes are innervated tissue bundles within the shell, which are connected by aesthete canals. Aesthete pores on the shell surface are typically found in clusters corresponding to subsurface bundles, with one megalaesthete usually being surrounded by up to 25 smaller micraesthetes, although these clusters can be evenly distributed over the valve surface (Hyman 1967). A megalaesthete contains a core of microvillous cells each bearing a single cilium, surrounded by one or sometimes two types of secretory cells. Nerve elements have been observed associated to both of these (Eernisse and Reynolds 1994). The aesthete canals form complex networks within the shell, connecting to the lateral epithelium, or penetrating the shell venter. The surface patterns of pores and the connective networks can both be used to diagnose species (e.g. Vendrasco et al. 2008, Sigwart 2009). The micraesthetes are single elongated cells branching from the base of the megalaesthete. Their ultrastructure has been described in detail by Eernisse and Reynolds (1994).

Although the primary use for aesthetes is uncertain, photoreception is generally accepted to be the most likely candidate in shallow water species (Boyle 1972, 1974, Omelich 1967, Vendrasco et al. 2008), though some also consider chemoreception to be a reasonable suggestion due to the presence of secretory elements (e.g. Baxter et al. 1987). In some chitons (Schizochitonidae, Chitonidae, Callochitonidae) the megalaesthetes have developed into larger 'shell eyes', intrapigmented ocelli which have aragonite lenses and a pigmented retinal cup surrounding rhabdomeric photoreceptors. In at least one species, the array of shell eyes conveys the ability to distinguish shapes, both in air and submerged in water (Speiser et al. 2011).

The girdle is the other dorsal surface of the chiton. It encircles the shell valves and is covered with a cuticle of mineralized spicules or scales, as well as specialized hairs or spines in some species. Some of these may be mechanosensory, as they are often innervated (Leise and Cloney 1982, Leise 1988). Additionally, photoreceptor cells have been found associated with spicules in Acanthochitona fascicularis, and it has been suggested that other species may have additional sensory capacity in girdle elements (Fischer et al. 1980).

Chitons have several sensory organs within the pallial cavity. Members of Chitonida possess a paired posterior sense organ, formerly refered to as an osphradium, an innervated and pigmented ridge at the base of the gill row (Lindberg and Sigwart 2015). The epithelium has been described in several species and differs considerably between taxa (Haszprunar 1987b) and may not be homologous in all of them. In the typical form, pigmented supporting cells surround sensory cells with basal somata and ciliated epithelial projections. In Acanthochitona communis the posterior sense organ (osphradium) is split into a sensory groove that has an ultrastructure similar to the typical osphradial epithelium, but also a mucous zone. The function of the chiton 'osphradium' remains unclear, with possibilities 


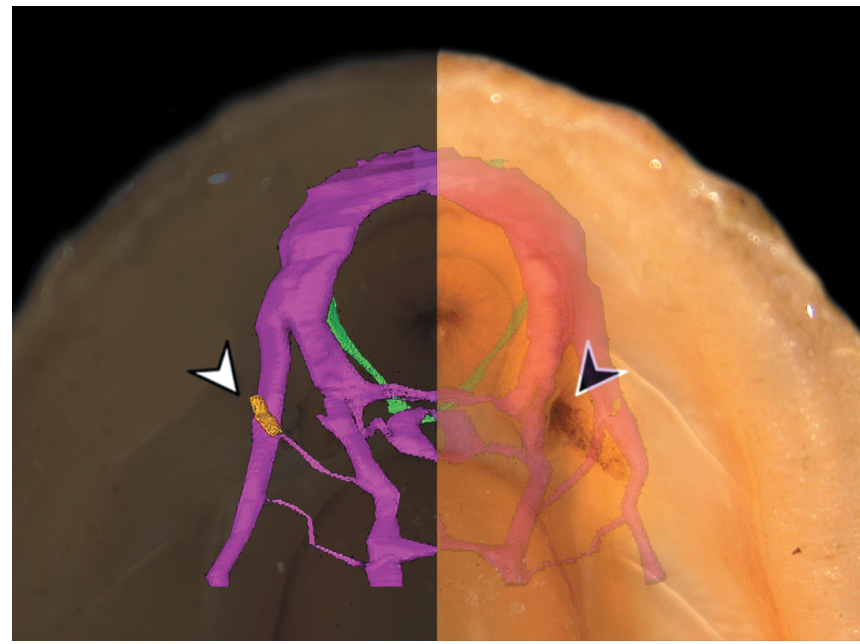

Fig. 18.6. Polyplacophora: The anterior nervous system of Leptochiton asellus visualized via tomographic reconstruction of semi-thin sections, overlaid on an image of a living specimen. Chevrons indicate the Schwabe organ.

including the monitoring of sediment loading (Yonge 1939) and the synchronization of spawning events (Haszprunar 1987b). Lepidopleuran chitons do not possess an osphradium or posterior sense organ.

In Lepidopleurida, the distal wall of the pallial cavity contains the 'lateral organs', small sensory knobs at regular intervals from just posterior of the mouth to a point parallel with the anus (Haszprunar 1987b, Sigwart et al. 2014). Their function is unknown, they have never been observed in species in the suborder Chitonida.

At the anterior of the pallial cavity in Lepidopleurida is the Schwabe organ (Fig. 18.6). This is a streak of brown pigmentation found either side of the mouth, extending laterally and posteriorly towards the foot (Sigwart et al. 2014). The pigmentation pattern varies taxonomically, but it is consistently present throughout Lepidopleurida. The Schwabe organ is innervated by the lateral nerve cord, slightly posterior to the first lateroventral connective. The sensory epithelium comprises mainly pigmented supporting cells, as well as multiciliary cells (with very high numbers of cilia, nearing 100 in some cases), and short sensory cells that carry projections up to the surface of the epithelium (Sigwart et al. 2014). The function of the Schwabe organ remains elusive, but it bears positional resemblance to the larval eyes (Heath 1904).

\section{Larval development}

The trochophore larvae of chitons possess a pair of larval eyes, pigmented spots located posterior of the prototroch, and the larvae respond to light (Pearse 1979). These cup-like organs contain eight or nine pigmented cells and a few (one to three in species studied to date) ciliated photoreceptors (Fischer 1980, Rosen et al. 1979). The larval eye lies adjacent to the lateral nerve cord, at a point slightly posterior to the first lateroventral commissure (Heath 1904). During metamorphosis, the eyes migrate dorsally and become hidden by the growing valves, before disappearing after around one month (Eernisse 2007, Kowalevsky 1883).
The larval apical organ, which contributes to settling cues and metamorphosis, comprises up to ten receptor cells which are connected to the cerebral commissure, and carries a large ciliary tuft (Friedrich et al. 2002). In addition to the large apical organ, chiton larvae possess a chemosensory ampullary system composed of four pairs of ampullary cells, found dorsolaterally and ventrolaterally in the pretrochal region of the larva. These cells are innervated by the anterior commissure and, unlike larval eyes, disappear during early metamorphosis (Haszprunar et al. 2002).

Initial development of the nervous system begins below the apical organ, where larval serotonergic cells begin to appear around one day post fertilization. Two pairs of these seem to initiate the rest of the neurogenic process, projecting posteriorly into the anterior central part of the cerebrobuccal ring. This then expands laterally and posteriorly to form the rest of the ring. Lastly, the development of the lateral and ventral nerve cords continues posteriorly and the sub- and supra-rectal connections are formed. Buccal ganglia form later, as do the ventral commissures which continue to increase in number during metamorphosis and still in juvenile chitons, though their position is not correlated to shell fields or muscles (Friedrich et al. 2002).

\section{Observations}

More than 60 species of chiton have contributed to studies of the nervous system in the past 200 years. These include members of both extant orders, Chitonida and Lepidopleurida, giving a decent taxonomic spread, though the latter may be slightly underrepresented.

The earliest detailed studies of polyplacophoran neuroanatomy were made by Plate 1896, 1898, 1899, 1901). Kowalevsky (1883) and Heath (1904) were among the first authors to describe chiton development and the ontogeny of the nervous system. Since then, chitons have been the subject of several microanatomical studies including those of Fischer (Fischer et al. 1980), Leise (Leise and Cloney 1982, Leise 1988), and Haszprunar (1987b). More recently, cutting edge technologies have also been employed in the study of nervous system structure and development, including immunocytochemistry and tomography (Faller et al. 2012, Moroz et al. 1994, Sigwart et al. 2014).

\section{SCAPHOPODA}

Scaphopods, the tusk shells, are infaunal animals found in soft marine sediments; most live in deep-sea environments of 100 $\mathrm{m}$ and deeper, but a few species are know from the intertidal (Glover et al. 2003). The long, tapered shell holds the viscera, with a club-shaped muscular foot at the wider, ventral end. Most species are slightly curved, and the convex side of the shell is the anterior aspect. The animals are usually positioned more or less vertically with the foot down and the narrow apex at or near the sediment surface. At the apex, there is a siphonlike extension of sensory mantle tissue known as the pavilion. Respiratory currents primarily flow through the apical opening downward, thus from dorsal to ventral. The gut is U-shaped; 
there is no head. The sexes are separate, and larvae take a lecithotrophic veliger form (Buckland-Nicks et al. 2002). The animals feed on detritus, microorganisms, or foraminifera which they collect with their elastic sensory tentacles called captacula. There are more than 900 described species of Recent scaphopods, which fall into ten families. The class is divided into two orders: Dentaliida and Gadilida, which are anatomically strikingly different (e.g. Steiner 1991, Faller et al. 2012). For example, the retraction of the muscular foot is enabled by extension in Dentaliida, but by inversion in Gadilida. The majority of studies have focused on members of the Dentaliida and certain generalizations may require further investigation in Gadilida.

\section{Nervous system architecture}

Scaphopods have a typical tetraneural molluscan nervous system, imposed on a highly modified body plan (Fig. 18.2). The oesophageal nerve ring is formed by the paired cerebral and pedal ganglia, which are connected by commissures and the cerebropedal connectives. There is considerable confusion over the orientation of anatomical body axes in these strange animals (Sumner-Rooney et al. 2015). Here we interpret the foot to be ventral, which is the most parsimonious arrangement and facilitates comparisons with other classes. Thus, the pedal ganglia are ventral and posterior of the cerebral ganglia (contra Deshayes 1825, Lacaze-Duthiers 1856, Foll 1889, Fischer-Piette and Franc 1969, Faller et al. 2012). The ring emits two pairs of major nerves, the ventral nerves innervate the foot, and the lateral nerves innervate the viscera (Deshayes 1825).

The cerebral ganglia are large and ovoid, fused by a short, wide commissure and are located at the anterior side of the animal beneath the buccal tube (Lacaze-Duthiers 1856). The central neuropil is completely surrounded by cell bodies, but demonstrates no subdivision within the ganglion (Faller et al. 2012, Fol 1889). In Entalina quinquangularis (Gadilida), the distribution of somata around the cerebral ganglia is fairly even, whereas in Antalis entalis (Dentaliida), there is a distinct aggregation of cell bodies at the dorsal margin (Faller et al. 2012). Fol (1889) described parts of the cerebral ganglia as being covered by large ganglionic cells, whereas the dorsal and anterior sides were surrounded by smaller ones.

The cerebral ganglia emit nerves that innervate the feeding structure of the scaphopod, the mantle, and the sensory captacula. The buccal nerves originate at the ventral side of the cerebral ganglia and run ventrally alongside the gut to the base of the buccal tube, where they branch into a major and a minor nerve (Fischer-Piette and Franc 1969). The internal lateral nerves flow from the cerebral ganglia and innervate the mantle tissue (Lacaze-Duthiers 1856). The captacula are innervated by two thick nerves that originate from the lateral parts of the cerebral ganglia; these enter two ridges bearing the captacula, where the nerves branch and enter the base of the individual tentacles. One fine nerve runs the length of each captaculum, ending in a captacular ganglion in the base of the bulbous head.

The pedal ganglia are located midway along the foot. The pedal ganglia themselves are pear-shaped, being narrow at the ventral and rounded at the dorsal ends, and connected by a short commissure (Fol 1889). They each emit three nerves into the lateral and distal regions of the foot, as well as a single median pedal nerve, which seems to originate from the connective between the two pedal ganglia (Fischer-Piette and Franc 1969). Fol (1889) asserted that aside from the cerebral ganglia, generally there were only a few cell bodies surrounding the other named ganglia and that this negated their classification as such; however Plate 1892) and later Faller et al. (2012) have demonstrated that the pedal ganglia in particular are surrounded by a thick somatal layer.

The pedal ganglia are connected to the cerebral and pleural ganglia by the cerebropedal connectives, which branch shortly ventral of the cerebral ganglia and then continue further dorsal to also connect with the pleural ganglion. The cerebral ganglia are immediately connected to the pleural ganglia by a pair of short cerebropleural connectives. The pleural ganglia are ovoid in shape and each emits two major nerves away from the cerebral ganglia (in addition to the connectives to the cerebral and pedal ganglia). The first pair are nerves that emerge from the dorsal part of the pleural ganglia, but turn to form branching nerves that innervate the mantle tissue at the ventral aperture of the shell and surround the muscular foot stalk (Lacaze-Duthiers 1856). The paired pleuro-visceral connectives emerge from the same point at the posterior of the pleural ganglia and extend posteriorly to connect to the visceral ganglia located lateral to the anus (Fischer-Piette and Franc 1969).

The two visceral ganglia are triangular in shape, with each corner emitting a major nerve (Lacaze-Duthiers 1856). One of these is the pleuro-visceral connective, but they are also interconnected by a commissure ventral to the anus, and each ganglion emits a long visceral nerve that runs along the remaining length of the body, finally ending in a swelling at the anterior side of the apical pavilion. A nerve ring at the posterior edge of the animal runs around the pavilion (Wanninger and Haszprunar 2003).

\section{Sensory organs}

Although there was one osphradium candidate proposed, based on a misinterpretation (Distaso 1905), scaphopods are widely agreed to lack any osphradium (Haszprunar 1987b, Reynolds 2002).

Scaphopods have large numbers of long, slender, specialized 'tentaculiform filaments' (Fol 1885) called captacula, which originate from two bands of tissue between the foot and the mantle (Fig. 18.7). These are primarily used for feeding, either passing particulate matter along ciliary bands or contracting to move it directly to the mouth, but they also have apparent tactile sensory capabilities (Gainey 1972, Lacaze-Duthiers 1856). A captaculum is divided into a long fine filament and a distal bulbous head, which has an alveolus or groove in the ventral face (Byrum and Ruppert 1994). This alveolus is thought to be the sensory component, and it and the rest of the head are covered in long cilia (Shimek 1988). The ciliation varies taxonomically, with arrangements ranging from cilia along the full length of the filament, intermittent ciliary tufts, or lacking cilia on the filament completely (Shimek 1988). Longitudinal muscle fibres surround 


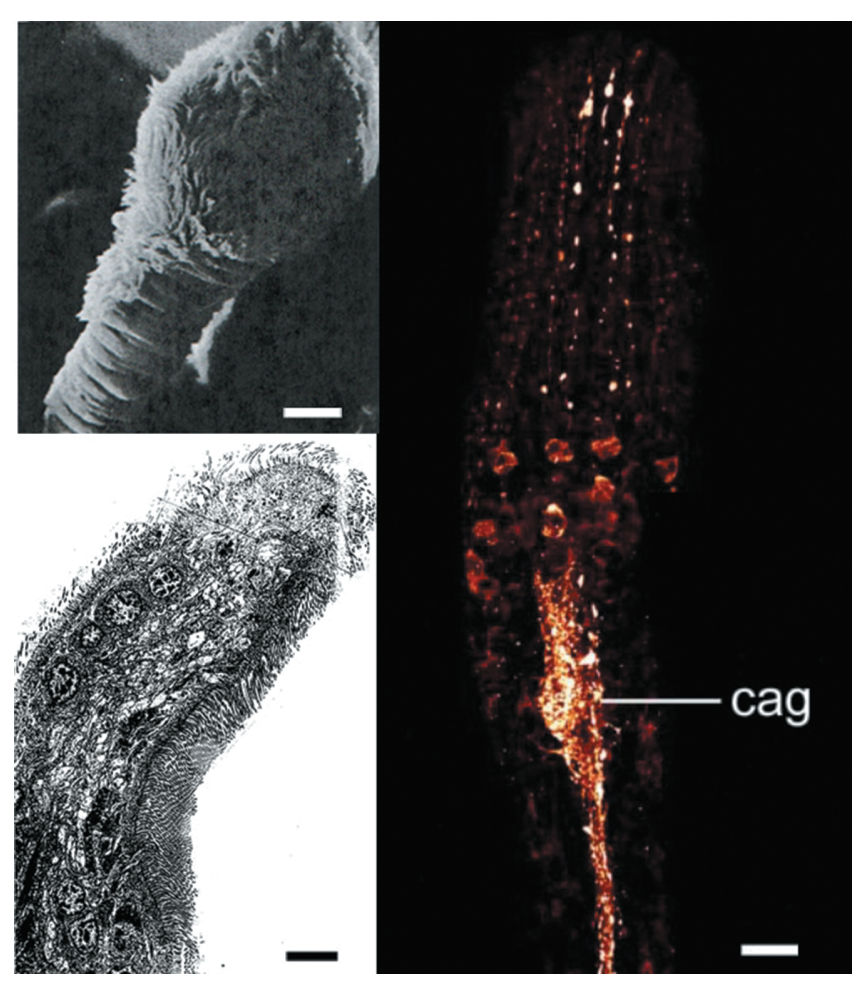

Fig. 18.7. Scaphopoda: The bulbs of captacula, specialized sensory tentacles of scaphopods. Clockwise: Top left, SEM image of Pulsellum salishorum (Gadilida) reproduced from Shimek (1988), scale bar $10 \mu \mathrm{m}$. Right, confocal image of FMRFamide-like immunoreactivity indicating locations of nerves in a captaculum in Antalis entails (Dentaliida), reproduced from Faller et al. (2012), with kind permission from Springer Science and Business Media. Scale bars $20 \mu \mathrm{m}$. Bottom left, TEM image of captacular head (sagittal section, including region distal of ganglion) in Graptacme calamus (Dentaliida) reproduced from Byrum and Ruppert (1994) with the permission of John Wiley and Sons.

a single nerve through the filament, which terminates in a captacular ganglion in the head of the captaculum, beneath the alveolus (Fig. 18.7). This ganglion emits several smaller nerves to the other side of the captaculum head (Faller et al. 2012, Fischer-Piette and Franc 1969). Beneath the ganglion and above the ganglionic cell bodies is a pair of large glandular cells. Two rows of glandular cells are also found beneath this, in the beginning of the captacular filament, with ducts exposed to the alveolus (Gainey 1972).

Mantle tissue lines the ventral (larger) and dorsal (narrow apex) openings of the shell. At the ventral (pedal) mantle cavity opening, a broad collar of tissue surrounds the foot and closes the aperture when the animal retracts fully into its shell. The outer margin of this tissue is sensory epithelium. Two main receptor cell types are found in the ventral mantle margin in Dentaliida: cylindrical swollen nerve processes reaching the epithelial surface and bearing up to 25 sensory cilia, and collar receptors with one cilium at the centre of a ring of microvilli (Steiner 1991). The relative abundance of these two cell types varies in different species, with the former being most common in Antalis sp. and the latter in Fustiaria sp. (Steiner 1991). In Cadulus subfusiformis, Entalina, and Pulsellum spp. (Gadilida), the primary receptors in the anterior mantle edge are located in papillae, which contain one or two ciliated neural processes with a basally located soma, and collar receptors are also found in C. subfusiformis (Reynolds 2002, Steiner 1991).
The dorsal mantle edge (the 'pavilion') is innervated by two fine nerves stemming originally from the visceral ganglia (Steiner 1991). In Rhabdus rectius the tissue of the pavilion contains three types of ciliary cells, located at the outer side, which appear to act as receptors (Reynolds 1992, Steiner 1991). There are also ciliated nerve process-type receptors found associated with the ciliary organ at the dorsal edge of members of Gadilida; however the ciliary organ itself is not considered likely to perform a sensory function (Steiner 1991).

A subradular organ is present as a specialized patch of sensory epithelium found in a furrow in a fold of the pharynx. This furrow contains both sensory and supporting cells, as well as several nerve cells projecting back to the buccal nerves (Fischer-Piette and Franc 1969). The subradular organ is thought to be gustatory, and Shimek and Steiner (1997) report the rejection of potential food items after contact with the mouth.

The statocysts are located immediately posterior to the pedal ganglia and innervated by the cerebro-pedal connective. They are almost spherical and contain many smaller statoliths (Lacaze-Duthiers 1856). The structure of the statoliths may differ between the two orders of scaphopod; in Antalis entalis (Dentaliida) the statocysts can be clearly identified using DAPI nuclear labelling, but in the Entalina quinquangularis (Gadilida) they are not easily visible (Faller et al. 2012).

\section{Larval development}

Scaphopods progress through a lecithotrophic veliger larva with a cap-like protoconch or larval shell (Buckland-Nicks et al. 2002). The apical organ is evident at hatching (in Antalis entalis) and the apical cells have long, fine cilia before the prototroch cilia are visible. Development of the nervous system is initiated by the appearance of two, and later four, serotonergic cells in the apical organ at around 42 hours post fertilization, shortly followed by a pair of lateral nerve cells (Wanninger and Haszprunar 2003). The somata of these six cells migrate to beneath the prototroch, prior to metamorphosis when the apical organ is lost. By this time, the beginnings of the adult nervous system are already present at the position where the four apical cells were fused. Captacula are strictly post-metamorphic, with the paired anlage of the developing captacula immediately appearing following metamorphosis (Wanninger and Haszprunar 2001). Around two days after metamorphosis, the buccal, lateral, and pedal nerves and ganglia are visible, and the visceral nerves have formed. Further development and ganglionization of the cerebral and pedal systems takes place in metamorphosed juveniles for at least two weeks post metamorphosis, but the essential structure of the nervous system is already in place in late larvae (Wanninger and Haszprunar 2003).

\section{Observations}

In total, anatomical studies of at least twenty species have contributed to our knowledge of the scaphopod nervous system (many early authors neglected to explicitly document species names of the specimens they described). Of these, seven are members of Gadilida, though in the majority of these cases the 
descriptions have focused on a specific aspect (usually captacula) or have lacked histological detail. We believe this order, and its many differences from Dentaliida, remains largely understudied. Aside from the work of Wanninger and Haszprunar (2003), there is also little known about the development of the nervous system, and again this study only includes a dentaliid, Antalis entalis.

The first observations of the scaphopod nervous system were made by Deshayes (1825), though a more detailed description including histological observations was made later by LacazeDuthiers (1856). Captacula have become a research focus, with several studies examining their microanatomy (Byrum and Ruppert 1994, Faller et al. 2012, Shimek 1988). The work of Faller et al. (2012), visualizing the central nervous system of a gadilid and a dentaliid scaphopod by immunohistochemistry, has also provided new insight into the structure of the cerebral ganglia in particular and highlighted taxonomic differences between the two orders.

\section{SOLENOGASTRES}

Solenogastres (also called Neomeniomorpha, or neomenioids) is a class of vermiform molluscs that were once combined with Caudofoveata in a single taxon, Aplacophora. There are over 250 living species of solenogasters, with 73 valid novel species described in a single modern monograph (Salvini-Plawen 1978) and many more described since then. The foot is present as a narrow strip in a longitudinal groove, which begins anteriorly as a pedal pit and continues ventrally along the length of the animal. Anterior to the mouth is a unique sensory atrial organ (or vestibulum, as it is called by some authors). The mantle cavity is small and located at the posterior end of the animal; there are no ctenidia but the mantle cavity may have supplementary respiratory structures and bears the copulatory organ. Solenogasters are hermaphroditic and use internal fertilization (Salvini-Plawen 1985, Buckland-Nicks et al. 2002, Todt and Wanninger 2010). The whole body is covered in a chitinous cuticle in which a carpet of spicules is embedded. Solenogasters are gliding animals that travel along the surface of the substratum, through the top layers of sandy sediments or climbing on their primary food animals, colonial cnidarians. They inhabit marine environments at wide-ranging depths, from the sublittoral (around 30 $\mathrm{m})$ to abyssal trenches. The animals range in size from less than $1 \mathrm{~mm}$ to around $30 \mathrm{~cm}$ long. There is a substantial literature concerning the anatomy of solenogasters, which has contributed to the descriptions given below, and many of these papers have been synthesized by comprehensive reviews (e.g. Salvini-Plawen 1985, Scheltema et al. 1994).

\section{Nervous system architecture}

Solenogasters exhibit the essential features of a molluscan nervous system; a circumoesophageal nerve ring is formed by the connections of the cerebral and pedal ganglia, which emit the medullary lateral and the ventral nerve cords respectively (Hubrecht 1881). The lateral nerve cords supply the lateral and dorsal regions of the body wall, as well as the midgut, circulatory system, mantle cavity, and reproductive system. The ventral nerves innervate the ventrolateral regions either side of the pedal groove.

The cerebral ganglia are present in one whole as two large fused hemiganglia. This structure is often kidney shaped, being thicker at the lateral edges than in the middle. In some species, such as Wirenia argentea, there is a slightly bilobed aspect to the posterior part of the ganglion, which is lacking in others (Heath 1911, Salvini-Plawen 1997, Todt et al. 2008). At the anterior side of the cerebral ganglion are three or more pairs of frontal swellings, sometimes called precerebral ganglia, though not strictly ganglionic in nature (see Richter et al. 2010). These innervate the atrial sense organ and the oral region. The cerebral ganglia also emit two buccal nerves, which originate between the cerebrolateral and the cerebropedal connectives, each ending in a buccal ganglion which is embedded within the gut wall beside or anterior to the radula (Heath 1911). These innervate the mouth and radular regions. The buccal ganglia themselves are connected by a buccal commissure. In some species there are up to three such commissures, the anteriormost of which is ventral to the pharynx and may bear small clusters of cell bodies, potentially interpreted as subradular ganglia (Heath 1911, Hyman 1967, Todt et al. 2008).

The cerebropedal connectives form the lateral parts of the circumoesophageal nerve ring, connecting the lateroventral parts of the cerebral ganglion to the pedal ganglia. The ring is completed by the large commissure between the two pedal ganglia, and in some species up to three of these commissures are present (Salvini-Plawen 1985, Todt et al. 2008). The first pair of ventral nerves emerges close to the cerebral ganglion and innervates the (anterior) pedal pit and the pedal gland, and also branch from the cerebral ganglion in the same region (Salvini-Plawen 1978, 1985, Todt et al. 2008). The pedal ganglia emit a pair of slender nerves to the posterior part of the pedal pit, as well as the ventral nerve cords, which travel through the ventrolateral side of the body either side of the pedal groove (Heath 1911, Todt et al. 2008). The two ventral nerve cords are joined at regular intervals by pedal commissures throughout the length of the body, with slight swellings of the cords where these commissures originate (Salvini-Plawen 1981). The layer of cell bodies around the central neuropil is thickened at these swellings, but as there are somata present surrounding the medullary cords on either side, these swellings are not classified as ganglia (Hubrecht 1881, Richter et al. 2010, Todt et al. 2008). Anti-serotonin staining shows that the neuropil of each ventral nerve cord is split into two separate fibres anteriorly, and into four posteriorly in $W$. argentea (Todt et al. 2008). In some species, the ventral nerve cords narrow and taper off towards the posterior part of the pedal groove; in others they form several large lateroventral connectives at the posterior extreme, and in some cases the ends of the two ventral nerve cords are connected by a large ventral commissure (Heath 1911).

The lateral nerve cords originate in a lateral swelling of the cerebral ganglion. This is sometimes called the lateral or pleural ganglion, but as it blends directly into the lateral nerve cord it cannot be called a true ganglion (Heath 1911, Hyman 1967). The first lateroventral connective runs between this 
lateral swelling and the pedal ganglion (in Wirenia argentea) or the second to fifth ventral cord swellings, and the last connects the posterior lateral cord to the final ventral swelling (SalviniPlawen 1985, Todt et al. 2008). These often emit smaller nerves which innervate the lateral body wall. In W. argentea, Todt et al. (2008) reported that the posteriormost lateral swelling emitted two lateroventral connectives, of which one curves round to fuse medially to the ventral nerve cord. At the posterior end, the two lateral nerve cords are joined by a suprarectal commissure which runs dorsal to the rectum and sometimes carries a large ovoid swelling (Hubrecht 1881, Pelseneer 1906).

\section{Sensory systems}

The atrial or pre-oral sense organ is a large sensory pad anterior to the mouth and is bordered by a horseshoe-shaped ciliary tract/band. It is innervated by the frontal swellings of the cerebral ganglion, and frontal nerves from the pleural ganglia. In most species it is withdrawn into the anterior part of the buccal cavity and extended hydrostatically when needed (SalviniPlawen 1985). The pad is roundly heart-shaped, the point being at the anterior, and-in some cases with a fused atrio-buccal cavity-connected to the mouth opening at the centre of the posterior wider edge. It is bordered by a band of cilia and irregularly placed setae, extending laterally from the edges of the pad, which are likely mechanosensory (Salvini-Plawen 1985). The central region of the pad is horseshoe shaped with its curve toward the anterior, and bends with its lateral limbs dorsally uniting at the roof of the cavity. The whole structure is covered in sensory papillae (cirri) in most species, which may be single or branching. Surrounding these is an epithelium with only a thin cuticle and possibly bearing microvilli (Salvini-Plawen 1985). The basal edge of the atrial sense organ is connected to a dense nerve network stemming from the frontal swellings and cerebral ganglia themselves (Todt and Salvini-Plawen 2004). The pedal commissure sac is a large, round structure found beneath and between the pedal ganglia in some species. It contains a liquid and six to ten free-floating cells which each bear a vacuole with a single central granule (Haszprunar 1986, Todt et al. 2008). The pedal commissure sac has been suggested to be a static sensory organ due to its innervation by the pedal ganglia. Thick nerves from these ganglia branch and penetrate the thick basal lamina and epithelial cells of the envelope (Haszprunar 1986). The presence of calcareous bodies in the lumen of the sac in Gymnomenia suggests a statolith-type movement sensor (Haszprunar 1986, Scheltema 1981).

The dorsoterminal sense organ is found invariably at the caudal end of the animal. Its structure varies considerably in different taxa. For example in Wirenia argentea, the dorsoterminal organ is a retractable sensory knob innervated by the lateral nerve cord posterior swellings (Todt et al. 2008), or from the suprarectal commissure (e.g. Salvini-Plawen 1978). The outside edge of the knob is covered by a thin cuticle and a concentric array of scales, which cover the knob when it is retracted. The central zone is not covered by cuticle but has a thick microvillous border, formed by supporting cells with pigment granules and oval nuclei (Haszprunar 1987a). Between these supporting cells, cellular processes from sensory cells with basal somata project towards the surface of the epithelium, often bearing between one and three cilia. Axonal processes of these sensory cells connect to the dorsoterminal nerves. Conversely, in Neomenia carinata the dorsoterminal organ is a sensory groove containing a short central ridge which separates it into two shallow clefts, often found on the ventral side of the animal (Haszprunar 1987a). The cells in these clefts bear short-rooted cilia and are in contact with nerves from the suprarectal commissure, so they are considered to be sensory. The cells lining the groove on either side are microvillous and have no cuticular covering, unlike the surrounding epithelium (Haszprunar 1987a). Additionally some species, such as Thieleherpia thulensis, have been found to possess a second dorsoterminal sense organ at the rear of the body (Salvini-Plawen 2003). Its dual innervation has led to the suggestion that the dorsoterminal sense organ arose from the fusion of two paired sense organs (Salvini-Plawen 1978).

\section{Larval development}

Solenogaster trocophore larvae disperse and metamorphose to the adult form on settlement to the benthos. The apical tuft is a larval sensory organ which comprises four apical cells which carry sensory flagella. These are incorporated into the test as the larva develops and approaches metamorphosis, and do not appear to contribute to the development of the adult nervous system (Baba 1940, Hadfield 1979). Instead, test cells beneath two depressions in the pretrochal region proliferate inwards and eventually form the basis for the cerebral ganglia (Fig. 18.7), which fuse later in development, as well as other components of the central nervous system (Buckland-Nicks et al. 2002, Okusu 2002). The pedal ganglia also appear around the same time (around three days post fertilization) in Epimenia babai, but their development has not been directly observed (Okusu 2002). In Rhopalomenia aglaopheniae and Nematomenia banyulensis, the pedal ganglia arise from further cell proliferation in the cerebral ganglia, but in Neomenia carinata they form in the same way as the cerebral ganglia, from the invagination of test cell depressions (Okusu 2002, Todt and Wanninger 2010; Fig. 18.8).

\section{Observations}

To date, neuroanatomical data have been gathered from around 25 different species from 18 (of 89 valid) genera. Heath (1911) was one of the first authors to provide a description of the neuroanatomy in Solenogastres. The work of Salvini-Plawen (e.g. 1985) expanded upon Heath's descriptions and gave more histological detail. The first studies to apply immunohistochemistry to the study of nervous systems have helped to characterise the anatomical distribution of different neural elements (Faller et al. 2012, Todt et al. 2008).

The fact that the dorsoterminal sense organs vary in their position, innervation, and structure both within and between classes suggests that these posterior sense organs (sensu Lindberg and Sigwart 2015) are not homologous with the osphradium of other molluscan groups, although this has been proposed by several authors (Haszprunar 1987a, Salvini-Plawen 1981). 


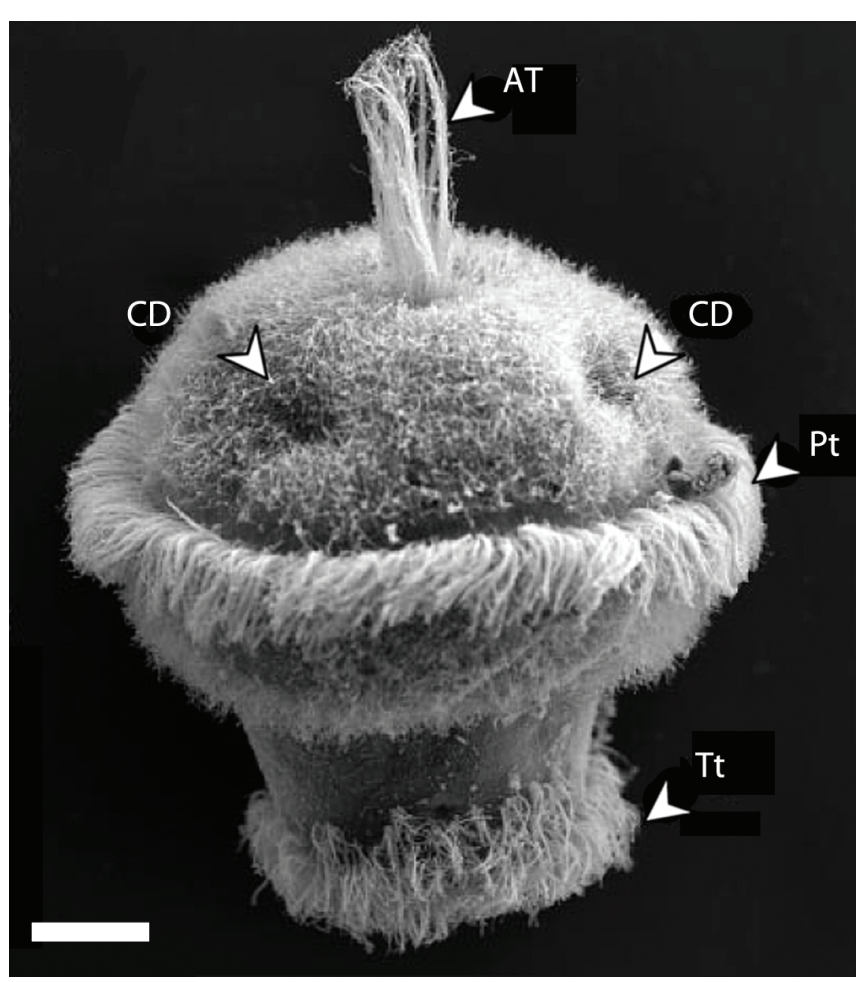

Fig. 18.8. Solenogastres: A one-day-old trochophore larva of Epimenia babai in ventral view, showing the paired ectodermal cerebral depressions (CD) where the cerebral ganglia begin to form, scale bar $50 \mu \mathrm{m}$. Figure $14 \mathrm{a}$ from Okusu (2002). Reprinted with permission from the Marine Biological Laboratory, Woods Hole, MA.

\section{CONCLUSIONS}

The osphradium, a putatively chemosensory organ found in some gastropods and bivalves, has been suggested as a synapomorphy of Mollusca, but there is very limited evidence for the homology of various structures called the osphradium (Sigwart et al. 2014). Lindberg and Sigwart (2015) distinguished two types of pigmented epithelial sensory structures, the osphradium sensu stricto as distinct from 'posterior sense organs' in several classes. In Caudofoveata and Solenogastres, the dorsoterminal sense organ has been called an osphradium (Haszprunar 1987a), though the structures in both classes differ from each other, and the ultrastructure as well as the position is considerably divergent from proposed osphradia in other groups. Monoplacophorans and scaphopods lack an osphradium, and the osphradium identified in some derived species of chitons are also not homologous to other molluscan osphradia (Lindberg and Sigwart 2015).

The perception of several of these groups as primitive, or at least morphologically homogenous, within their respective classes, has perhaps limited the interest in comparative examinations of the neuroanatomical and sensory diversity within each taxon. The studies of different classes have been driven mainly by specialists in a particular taxon, and have a varying emphasis in each group. There are still gaps where future work can determine variability within and among living groups (e.g. Gadilida is almost totally unrepresented within scaphopods). Much work on the Monoplacophora has focused on its putatively basal position within molluscan phylogeny and on comparisons to Polyplacophora and to patellomorph limpets. The monoplacophoran living species clearly demonstrate a significant degree of neuroanatomical diversity. It is interesting to speculate that the relatively enlarged buccal ganglia and pedal ganglia, features of Neopilina and Micropilina spp. (Fig. 18.4), perhaps not coincidentally unite taxa that are recovered as sistergroups in molecular phylogeny (Stöger et al. 2013).

Neuroanatomy has been crucial to the study of molluscs. Indeed, both aplacophoran classes as well as scaphopods were historically considered to be worms, but the organization of their nervous systems helped early comparative anatomists recognize these animals as molluscs (Deshayes 1825). Now, after nearly two centuries of study on molluscan nervous systems, novel imaging techniques, including tomographic reconstruction and immunohistochemistry, have opened new frontiers of research. Knowledge of these five diverse and interesting clades is a strong platform for more detailed studies and for the application of a neurophylogenetic approach to questions in molluscan evolution.

\section{REFERENCES}

Baba, K. (1940). The early development of a Solenogastre, Epimenia verrucosa (Nierstrasz). Annotationes Zoologicae Japonenses, 19, 107-114.

Baxter, J.M., Jones, A.M., and Sturrock, M.G. (1987). The infrastructure of aesthetes in Tonicella marmorea (Polyplacophora; Ischnochitonina) and a new functional hypothesis. Journal of Zoology, 211, 589-604.

Boettger, C.R. (1956). Beitrage zur Systematik der Urmollusken (Amphineura). Zoologischer Anzeiger Suppl., 19, 223-256.

Boyle, P.R. (1972). The aesthetes of chitons. 1. Role in the light response of whole animals. Marine Behaviour and Physiology, 1, 171-184.

Boyle, P.R. (1974). The aesthetes of chitons. II. Fine structure in Lepidochitona cinereus (L.). Cell \& Tissue Research, 153, 383-398.

Boyle, P.R. (1975). Fine structure of the subradular organ of Lepidochitona cinereus L. (Mollusca: Polyplacophora). Cell \& Tissue Research, 162, 411-417.

Buckland-Nicks, J., Gibson, G., and Koss, R. (2002). Phylum Mollusca: Polyplacophora, Aplacophora, Scaphopoda. In Atlas of Marine Invertebrate Larvae, pp. 245-226. Academic Press, New York.

Byrum, C.A. and Ruppert, E.E. (1994). The ultrastructure and functional morphology of a captaculum in Graptacme calamus (Mollusca, Scaphopoda). Acta Zoologica, 75, 37-46.

Deshayes, G.-P. (1825). Anatomie et monographie du genre Dentale. Mémoires de La Society d'Histoire Naturelle de Paris, 2, 321-378.

Dethier, M.N. and Duggins, D.O. (1984). An indirect commensalism between marine herbivores and the importance of competitive hierarchies. American Naturalist, 124, 205-219.

Distaso, A. (1905). Sull'anatomia degli scafopodi. Zoologischer Anzeiger, 29, 271-278.

Eernisse, D.J. (2007). Chitons. In M.W. Denny and S.D. Gaines, eds. Encyclopedia of Tidepools and Rocky Shores, pp. 127-133. University of California, Berkeley.

Eernisse, D.J. and Reynolds, P.D. (1994). Polyplacophora. In F.W. Harrison and A.J. Kohn, eds. Microscopic Anatomy of Invertebrates. Vol. 5. Mollusca 1, pp. 55-110. Wiley-Liss, New York. 
Faller, S., Holger Roth, B., Todt, C., Schmidt-Rhaesa, A., and Loesel, R. (2012). Comparative neuroanatomy of Caudofoveata, Solenogastres, Polyplacophora, and Scaphopoda (Mollusca) and its phylogenetic implications. Zoomorphology, 131, 149-170.

Fischer, F.P. (1980). Fine structure of the larval eye of Lepidochitona cinerea. Spixiana, 3, 53-57.

Fischer, F.P., Maile, W., and Renner, M. (1980). Die Mantelpapillen und Stacheln von Acanthochiton fascicularis L. (Motion Polyplacophora). Zoomorphology, 94, 121-131.

Fischer-Piette, E. and Franc, A. (1969). Classe des scaphopodes. In P-P Grassé, ed. Traité de Zoologie, Mollusques, Gasteropodes et Scaphopodes, pp. 987-1017. Mason, Paris.

Fol, H. (1885). Sur l'anatomie microscopique du Dentale (note). Comptes Rendus Hebdomadaires Des Seances de l'Academie Des Sciences, 100.

Fol, H. (1889). Sur l'anatomie microscopique du Dentale. Archives de Zoologie Expérimentale et Générale, Deuxième Série, Tome 7, 91-148.

Friedrich, S., Wanninger, A., Brückner, M., and Haszprunar, G. (2002). Neurogenesis in the mossy chiton, Mopalia muscosa (Gould) (Polyplacophora): evidence against molluscan metamerism. Journal of Morphology, 253, 109-117.

Gainey, L.F. (1972). The use of the foot and the captacula in the feeding of Dentalium (Mollusca: Scaphopoda). The Veliger, 15, $29-34$.

Gantner, R. (1987). Lepidochitona monterosatoi (Polyplacophora): Außere Morphologie und Nervensystem. Institut Für Zoologie, Technische Universität München, München.

Giribet, G., Okusu, A., Lindgren, A.R., Huff, S.W., Schrödl, M., and Nishiguchi, M.K. (2006). Evidence for a clade composed of molluscs with serially repeated structures: monoplacophorans are related to chitons. Proceedings of the National Academy of Sciences USA, 103, 7723-7728.

Glover, E., Taylor, J., and Whittaker, J. (2003). Distribution, abundance, and foraminiferal diet of an intertidal scaphopod, Laevidentalium lubricatum, around the Burrup Peninsula, Dampier, Western Australia. In FE Wells, DI Walker, and DS Jones, eds. The Marine Flora and Fauna of Dampier, Western Australia, pp. 226-240. Western Australian Museum, Perth.

Gonor, J.J. (1979). Monoplacophora. In AC Giese and JS Pearse, eds. Reproduction of Marine Invertebrates. Vol. 5. Molluscs: Pelecypods and lesser classes, pp. 87-94. Academic Press, New York.

Hadfield, M.G. (1979). Aplacophora. In AC Giese and JS Pearse, eds. Reproduction of Marine Invertebrates. Vol. 5. Molluscs: Pelecypods and lesser Classes, pp. 1-26. Academic Press, New York.

Harzsch, S. (2006). Neurophylogeny: architecture of the nervous system and a fresh view on arthropod phyologeny. Integrative and Comparative Biology, 46, 162-194.

Haszprunar, G. (1986). Fein morphologische Untersuchungen an Sinesstruckturen urspruenglicher Solenogastres. Zoologischer Anzeiger, 217, 345-362.

Haszprunar, G. (1987a). The fine morphology of the osphradial sense organs of the Mollusca. IV. Caudofoveata and Solenogastres. Philosophical Transactions of the Royal Society of London B Biological Sciences, 315, 63-73.

Haszprunar, G. (1987b). The fine morphology of the osphradial sense organs of the Mollusca. III. Placophora and Bivalvia. Philosophical Transactions of the Royal Society of London B Biological Sciences, 315, 37-61.

Haszprunar, G., Friedrich, S., Wanninger, A., and Ruthensteiner, B. (2002). Fine structure and immunocytochemistry of a new chemosensory system in the chiton larva (Mollusca: Polyplacophora). Journal of Morphology, 251, 210-218.
Haszprunar, G. and Ruthensteiner, B. (2013). Monoplacophora (Tryblidia)—some unanswered questions. American Malacological Bulletin, 31, 189-194.

Haszprunar, G. and Schaefer, K. (1997a). Anatomy and phylogenetic significance of Micropilina arntzi (Mollusca, Monoplacophora, Micropilinidae Fam. Nov.). Acta Zoologica, 77, 315-334.

Haszprunar, G. and Schaefer, K. (1997b). Monoplacophora. In FW Harrison and AJ Kohn, eds. Microscopic Anatomy of Invertebrates. Vol. 6 B. Mollusca III, pp. 415-457. Wiley-Liss, New York.

Heath, H. (1904). The larval eye of chitons. Proceedings of the Academy of Natural Sciences of Philadelphia, 56.

Heath, H. (1911). The Solenogastres. Report of the Scientific Results of the Expedition of the Tropical Pacific Steamer Albatross. Memoirs of the Museum of Comparative Zoology, Harvard, 14, 360pp.

Hubrecht. (1881). Pronemia Sluiteri. Nied. Archiv für Zoologie Suppl. I.

Hyman, L.H. (1967). The Invertebrates. Vol VI. Mollusca I. McGrawHill, New York.

Kano, Y., Kimura, S., Kimura, T., and Warén, A. (2012). Living Monoplacophora: morphological conservatism or recent diversification? Zoologica Scripta, 41, 471-488.

Kocot, K.M., Cannon, J.T., Todt, C., et al. (2011). Phylogenomics reveals deep molluscan relationships. Nature, 477, 452-456.

Kowalevsky, M.A. (1883). Embryogénie du Chiton polii (Philippi) avec quelques remarques sur le développement des autres Chitons. Annales Du Museum d'Histoire Naturelle de Marseille, T1.

Lacaze-Duthiers, H. (1856). Histoire de l'organisation et développement du Dentale. Annales Des Sciences Naturelles, Quatrième Series, Tome 6, 319-385.

Leise, E.M. (1988). Sensory organs in the hairy girdles of some mopaliid chitons. American Malacological Bulletin, 6, 141-151.

Leise, E.M. and Cloney, R.A. (1982). Chiton integument: ultrastructure of the sensory hairs of Mopalia muscosa (Mollusca: Polyplacophora). Cell \& Tissue Research, 223, 43-59.

Lemche, H. and Wingstrand, K.G. (1959). The anatomy of Neopilina galatheae Lemche, 1957. In AF Brunn, S Greve, R Spaerk, and T Wolff, eds. The Galathea Report. Danish Sciences, Copenhagen.

Lindberg, D.R. (2009). Monoplacophorans and the origin and relationships of mollusks. Evolution: Education and Outreach, 2, 191-203.

Lindberg, D.R. and Sigwart, J.D. (2015). What is the molluscan osphradium? A reconsideration of homology. Zoologischer Anzeiger, 256, 14-21.

Mizzarro-Wimmer, M. and Salvini-Plawen, L.v. (2001). Praktische Malakologie: Beiträge zur vergleichend-anatomischen Bearbeitung der Mollusken, pp. 1-188. Springer, Berlin.

Moroz, L., Nezlin, L., Elofsson, R., and Sakharov, D. (1994). Serotonin- and FMRFamide-immunoreactive nerve elements in the chiton Lepidopleurus asellus (Mollusca, Polyplacophora). Cell \& Tissue Research, 275, 277-282.

Moseley, N.T. (1885). On the presence of eyes in the shells of certain Chitonidae and on the structure of these organs. Quarterly Journal of Microscopic Science, 25, 37-60.

Nielsen, C., Haszprunar, G., Ruthensteiner, B., and Wanninger, A. (2007). Early development of the aplacophoran mollusc Chaetoderma. Acta Zoologica, 88, 231-247.

Okusu, A. (2002). Embryogenesis and development of Epimenia babai (Mollusca Neomeniomorpha). Biological Bulletin, 203, 87-103.

Omelich, P. (1967). The behavioral role and structure of the aesthetes of chitons. The Veliger, 10, 77-82.

Pearse, J.S. (1979). Polyplacophora. In AC Giese and JS Pearse, eds. Reproduction of Marine Invertebrates. Vol. 5. Molluscs: Pelecypods and Lesser Classes, pp. 27-86. Academic Press, New York. 
Pelseneer, P. (1906). The Amphineura. In ER Lankester, ed. A Treatise on Zoology. Part V. Mollusca, pp. 40-65. Adam \& Charles Black, London.

Plate, L.H. (1892). Über den Bau und die Verwandtschaftsbezeihungen der Solenoconchen. Zoologisches Jahrbücher. Abteilung Für Anatomie und Ontogenie der Tiere, 5, 301-386.

Plate, L.H. (1896). Über die Organisation einiger Chitonen. Verhandlungen der Deutschen Zoologischen Gesellschaft, 6, 168-176.

Plate, L.H. (1898). Über primitive Organisationsverhältnisse, Viviparie und Brutpflege bei Chitonen. Sitzungsberichte der Königlich Preussischen Akademie der Wissenschaften, 14, 213-217.

Plate, L.H. (1899). Die Anatomie und Phylogenie der Chitonen. Fauna Chilensis 2(1), Zoologische Jahrbücher, Abteilung für Systematik, Ökologie und Geographie der Tiere 2, 15-216.

Plate, L.H. (1901). Die Anatomie und Phylogenie der Chitonen. Zoologische Jahrbücher, 5, 281-600.

Redl, E. and Salvini-Plawen, L.v. (2009). Das Nervensystem der Caudofoveata (Mollusca): eine vergleichend-anatomische und histologische Studie, p. 201. VDM, Saarbrücken.

Reynolds, P.D. (1992). Distribution and ultrastructure of ciliated sensory receptors in the posterior mantle epithelium of Dentalium rectius Mollusca, Scaphopoda. Acta Zoologica, 73, 263-270.

Reynolds, P.D. (2002). The Scaphopoda. Advances in Marine Biology, 42, 137-236

Richter, S., Loesel, R., Purschke, G., et al. (2010). Invertebrate neurophylogeny: suggested terms and definitions for a neuroanatomical glossary. Frontiers in Zoology, 7:29.

Rosen, M.D., Stasek, C.R., and Hemans, C.O. (1979). The ultrastructure and evolutionary significance of the ocelli in the larva of Katharina tunicata (Mollusca, Polyplacophora). The Veliger, 22, $173-178$.

Ruthensteiner, B., Schropel, V., and Haszprunar, G. (2010). Anatomy and affinities of Micropilina minuta Waren, 1989 (Monoplacophora: Micropilinidae). Journal of Molluscan Studies, 76, 323-332.

Salvini-Plawen, L.v. (1968). Über Lebendbeobachtungen an Caudofoveata (Mollusca, Aculifera) nenst Bemerkungen zum System der Klasse. Sarsia, 31, 105-126.

Salvini-Plawen, L.v (1972). Zur Morphologie und Phylogenie der Mollusken: Die Beziehungen der Caudofoveata und der Solenogastres als Aculifera, als Mollusca und als Spiralia. Zeitschrift für Wissenschaftliche Zoologie, 184, 205-394.

Salvini-Plawen, L.v. (1975). Mollusca, Caudofoveata. In J-A Sneli, E Sivertsen, and $\mathrm{H}$ Brattstrøm, eds. Marine Invertebrates of Scandinavia No. 4. Vol. 4. $55 \mathrm{pp}$. Universitetsforlaget, Oslo.

Salvini-Plawen, L.v. (1978). Antarktische und subantarktische Solenogastres (eine Monographie: 1898-1974). Zoologica, 128, $1-305$.

Salvini-Plawen, L.v. (1980). A reconsideration of systematics in the Mollusca (phylogeny and higher classification). Malacologia, 19, $249-278$

Salvini-Plawen, L.v. (1981). On the origin and evolution of the Mollusca. Atti Dei Convegni Lincei, 49, 235-293.

Salvini-Plawen, L.v. (1985). Early evolution and primitive groups. In ER Trueman and MR Clarke, eds. The Mollusca. Vol. 10. Evolution, pp. 59-150. Academic Press, Orlando.

Salvini-Plawen, L.v. (1997). Systematic revision of the Epimeniidae (Mollusca: Solenogastres). Journal of Molluscan Studies, 63, 131-155.

Salvini-Plawen, L.v. (2003). On the phylogenetic significance of the aplacophoran Mollusca. Iberus, 21, 67-97.

Schaefer, K. and Haszprunar, G. (1997). Anatomy of Laevipilina antarctica, a monoplacophoran limpet (Mollusca) from Antarctic waters. Acta Zoologica, 77, 295-314.
Scheltema, A.H. (1981). Comparative morphology of the radulae and alimentary tracts in the Aplacophora. Malacologia, 20, 361-383.

Scheltema, A.H. (1995). Falcidens poias, a new species of chaetoderm Aplacophora from Rottnest Island, Western Australia (Chaetodermomorpha, Chaetodermatidae). Molluscan Research, 16, 45-49.

Scheltema, A.H., Tscherkassky, M., and Kuzirian, A.M. (1994). Aplacophora. In FW Harrison and AJ Kohn, eds. Microscopic Anatomy of Invertebrates. Vol. 5. Mollusca 1, pp. 13-54. Wiley-Liss, New York.

Shigeno, S., Sasaki, T., and Haszprunar, G. (2007). Central nervous system of Chaetoderma japonicum (Caudofoveata, Aplacophora): implications for diversified ganglionic plans in early molluscan evolution. Biological Bulletin, 213, 122-134.

Shimek, R.L. (1988). The functional morphology of scaphopod captacula. The Veliger, 30, 213-221.

Shimek, R.L. and Steiner, G. (1997). Scaphopoda. In FW Harrison and AJ Kohn, eds. Microscopic Anatomy of Invertebrates. Vol. 6B. Mollusca 2, pp. 719-781. Wiley-Liss, New York.

Sigwart, J.D. (2009). The deep-sea chiton Nierstraszella (Mollusca: Polyplacophora: Lepidopleurida) in the Indo-West Pacific: taxonomy, morphology and a bizarre ectosymbiont. Journal of Natural History, 43, 447-468.

Sigwart, J.D. and Lindberg, D.R. (2015). Consensus and confusion in molluscan trees: evaluating morphological and molecular phylogenies. Systematic Biology, In press.

Sigwart, J.D., Sumner-Rooney, L.H., Schwabe, E., Hess, M., Brennan, G.P., and Schrödl, M. (2014). A new sensory organ in 'primitive' molluscs (Polyplacophora: Lepidopleurida), and its context in the nervous system of chitons. Frontiers in Zoology, 11:7.

Sigwart, J.D. and Sutton, M.D. (2007). Deep molluscan phylogeny: synthesis of palaeontological and neontological data. Proceedings of the Royal Society of London B Biological Sciences, 274, 2413-2419.

Smith, S.A., Wilson, N.G., Goetz, F.E., et al. (2011). Resolving the evolutionary relationships of molluscs with phylogenomic tools. Nature, 480, 364-367.

Speiser, D.I., Eernisse, D.J., and Johnsen, S. (2011). A chiton uses aragonite lenses to form images. Current Biology, 21, 665-670.

Steiner, G. (1991). Observations on the anatomy of the scaphopod mantle and the description of a new family, the Fustiariidae. American Malacological Bulletin, 9, 1-20.

Stöger, I., Sigwart, J.D., Kano, Y., et al. (2013). The continuing debate on deep molluscan phylogeny: evidence for Serialia (Mollusca, Monoplacophora + Polyplacophora). BioMed Research International, 2013, 1-18.

Strausfeld, N.J. and Andrew, D.R. (2011). A new view of insectcrustacean relationships I. Inferences from neural cladistics and comparative neuroanatomy. Arthropod Structure and Development, 40, 276-288.

Sumner-Rooney, L.H., Schrödl, M., Lodde-Bensch, E., Lindberg, D.R., Heß, M., Brennan, G.P., and Sigwart, J.D. (2015). A neurophylogenetic approach provides new insight to the evolution of Scaphopoda. Evolution and Development, In press.

Sutton, M.D., Briggs, D.E.G., Siveter, D.J., Siveter, D.J., and Sigwart, J.D. (2012). A Silurian armoured aplacophoran and implications for molluscan phylogeny. Nature, 490, 94-97.

Sutton, M.D. and Sigwart, J.D. (2012). A chiton without a foot. Palaeontology, 55, 401-411.

Todt, C., Büchinger, T., and Wanninger, A. (2008). The nervous system of the basal mollusk Wirenia argentea (Solenogastres): a study employing immunocytochemical and 3D reconstruction techniques. Marine Biology Research, 4, 290-303. 
Todt, C. and Salvini-Plawen, L.v. (2004). Ultrastructure and histochemistry of the foregut of Wirenia argentea and Genitoconia rosea (Mollusca, Solenogastres). Zoomorphology, 123, 65-80.

Todt, C. and Wanninger, A. (2010). Of tests, trochs, shells, and spicules: Development of the basal mollusk Wirenia argentea (Solenogastres) and its bearing on the evolution of trochozoan larval key features. Frontiers in Zoology, 7:6.

Vendrasco, M.J., Fernandez, C.Z., Eernisse, D.J., and Runnegar, B. (2008). Aesthete canal morphology in the Mopaliidae (Polyplacophora). American Malacological Bulletin, 25, 51-69.

Wanninger, A. and Haszprunar, G. (2001). The expression of an engrailed protein during embryonic shell formation of the tusk-shell, Antalis entalis (Mollusca, Scaphopoda). Evolution and Development, 3, 312-321.
Wanninger, A. and Haszprunar, G. (2003). The development of the serotonergic and FMRF-amidergic nervous system in Antalis entalis (Mollusca, Scaphopoda). Zoomorphology, 122, 77-85.

Wilson, N.G., Rouse, G.W., and Giribet, G. (2010). Assessing the molluscan hypothesis Serialia (Monoplacophora + Polyplacophora) using novel molecular data. Molecular Phylogenetics and Evolution, 54, 187-193.

Wingstrand, G. (1985). On the anatomy and relationships of the Recent Monoplacophora. In Galathea Report (pp. 1-94). Danish Sciences, Copenhagen.

Yonge, C.M. (1939). On the mantle cavity and its contained organs in the Loricata (Placophora). Quarterly Journal of Microscopical Science, 81, 367-390. 